\title{
Chapter 6. Memories of Ridge-Poles and Cross-Beams: The categorical foundations of a Rotinese cultural design
}

\author{
James J. Fox
}

\section{Introduction}

In the classical art of memory from Roman times to the Renaissance, the house was made to serve as a structure for remembering. An imagined construction - with a succession of entry ways, passages, courtyards and rooms, all appropriately furnished - was used to fix the memory of specific objects. To recall these objects, one had only to journey through this familiar mnemonic space and to 'recollect' the memory of the objects that one had purposely stored in a particular place within the house. Images posed in ordered locations within a familiar architecture formed the basis of a complex mnemonic artifice known popularly as a 'memory palace' (Yates 1966). ${ }^{1}$

The structure of many Austronesian houses suggests features similar to those of a memory palace. Austronesian houses are ordered structures that minimally distinguish the categories of 'inside' and 'outside' and more generally establish a progression of designations within a defined internal space. Different parts of the house are identified with specific objects and specific activities.

Often the house itself is conceived as part of a wider-oriented space, which may be grounded in an ordered cosmology. This preoccupation with orientation may require that the proper placement of objects, the location of persons and the performance of cultural activities all occur in reference to the symbolic coordinates expressed in the house. As such, the house becomes more than an architectural design for the 'indwelling' of cultural traditions. It becomes in effect the prime structure for the performance of what are deemed to be those traditions. More than just a 'memory palace', an Austronesian house can be the theatre of a specific culture, the temple of its ritual activities. As in the West, a 'memory palace' of this kind may be regarded as a cosmological forum, a 'theatre of the world.' 2

On the island of Roti, the traditional house can be considered as such a memory palace. It is not, however, simply an abstract template for the storage of selected memories but rather a physical structure for the detailed preservation of specific elements of cultural knowledge. The house's posts, beams, spars, and 
even the spaces between these spars, as well as all of the house's levels, partitions, subdivisions and internal demarcations are specifically named; and each location is assigned a symbolic image. The house on Roti thus preserves the same relationship between image, object and location in a fixed physical form as an artfully contrived memory palace.

The Rotinese house is also the place for the performance of rituals or, equally important, the reference point for those rituals performed 'outside the house'. Here the house functions as a fundamental 'intermediate' structure: in relation to the person, it is itself a 'body' and serves as a macrocosm (a replicate body) for ritual performance; in relation to a wider symbolic universe, the house is itself a microcosm that replicates the order of the world. Performances within the house thus function at two levels simultaneously referring to both the person and the cosmos.

Critically important to the house as the locus of ritual performance is an insistence on 'remembering'. Thus one of the most frequent refrains in Rotinese ritual performances is the exhortation to remember: 'Do continue to remember and always bear in mind'.

This refrain is generally stated as a preface to a longer ritual statement and often occurs among the first lines that open a ritual speech. In the language of mortuary rituals, however, this refrain can be used to carry even greater significance. It may be chanted as the direct speech of the deceased instructing his descendants. In the rituals for welcoming a bride into her new house, this same exhortation to remember can become so densely linked to metaphors of the house that specific structures within the house become the physical memento of the event itself.

These excerpts from an address to the bride's group hint at the density of this imagery:

Sadi mafandendelek

Ma sadi masanenedak ...

Hu ndia de lole faik ia dalen

Ma lada ledok ia tein

Nde bena emi uma di madadi

Ma emi eda ai matola ...

\section{Lakameni tutui}

De ana tui ta sala don

De don nai uma-lai

Ma nggaemeni o'olu
Do continue to remember

And always bear in mind ...

Because on this good day

And at this fine time

Your house posts begin

And your tree ladder appears ...

The lakameni tree tells its leaves

It tells its leaves but lacks no leaves

For its leaves are in the upper house

And the nggaemeni sheds its bark 
De olu ta sala tean

De tean nai la'o-dale.

De kae mai uma-lai

Ma hene mai la'o-dale

Te tean nai uma-lai

Ma don nai la'o-dale.
It sheds its bark but lacks no hard core

For its hard core is near the fireplace.

Climb up into the upper house

And mount to the fireplace

For the hard core is in the upper house

And the leaves are near the fireplace.

The reply, in ritual language, of the bride's group extends this imagery which transforms the house into a remembrance of the event.

Nde bena lole faik ia dalen

Ma lada ledok ia tein-na, Ke-fetok-ka, ana lali

Ma tai-inak-ka, ana keko

$N d e$ bena ana keko mai uma-di

Ma ana lali mai eda-ai ...

Nde bena ana molo tunga lelete

Ma ana tabu tunga fifino ...

Fo ela leo bena

Ke-fetok-ka, ana molo

Ma tai-inak-ka, ana tabu

Fo ela bena eda-ai natetu

Ma uma-di nakatema.

Fo daeng-nga ela

Ana dadi neu koni-keak

Ma ana moli neu hate-haik

Nduku do-na

Ma losa nete'en-na neu.
Thus on this good day

And at this fine time,

The girl-child, she moves

And the female-child, she stoops

Stooping she comes to the house posts

Moving she comes to the tree ladder ...

Thus she steps along a bridge

And she sets foot along a path ...

So let it be

That the girl-child, she steps

And the female-child, she sets foot

That the tree ladder be erect

And the house posts be set.

Let the meaning be

That it become a remembrance

And it grow as a memento

For all times

And for all ages.

Here the idea of remembering, based on the verbal pair neda//ndele, implies a reflection that focuses on the house. The order and solidarity of the house is an assurance of the strength of the marriage. The transformation of an object into a remembrance (koni-keak//hate-haik) points to Rotinese ideas of knowing. The house is architecturally, if not archetypically, a significant locus for two forms of knowledge.

\section{Two Forms of Knowledge: Ndolu and Lelak}

The Rotinese distinguish between two kinds of knowledge. The first is strategic or technical knowledge which is known as ndolu. Such 'expert' knowledge is required in planning, construction and fabrication. As an architectural structure of considerable complexity, the traditional house is a 
prime exemplification of $n d o l u$. The construction of the traditional house is based on a specialized knowledge of measurements and proportions: multiples of so many armspans or fingerwidths, so many spars of an even number to so many beams of an odd number. The craft of construction is much like the art of weaving which requires a minute knowledge of the arrangement of threads and their interrelations. That these crafts are analogous is recognized on Roti. A woman may not tie, dye or weave a cloth while a house is under construction.

There is also a second form of knowledge that involves a deep understanding of cultural matters, of ritual and of tradition. This knowledge is known as lelak. As a cultural creation with elaborate symbolic meaning, the traditional house is also a prime embodiment of this lelak. What makes a house into a repository of cultural memory, rather than just a skilful arrangement of posts and beams, is lelak. To 'know' the house in this sense is to comprehend the basis of Rotinese culture. A portion of the knowledge about the house is vested in a critically important narrative that is intended to explain the origin of the house. Other knowledge of the house is linked to the life cycle rituals, whose performance is associated with appropriate locations within the house.

In Rotinese terms, the house is not simply the coincidence of two forms of knowledge - the expert knowledge of technical construction and the ritual knowledge of cultural design - but rather their combination and fusion. As it is expressed in ritual language, cultural design requires lelak as construction requires ndolu. In parallel language, these two terms are paired to form a single dyadic set. Lelak is supposed to provide the conceptual framework for ndolu.

To acquire the expert knowledge of the construction of a house, one may apprentice oneself to a master builder (ndolu ina); to acquire ritual comprehension of the house, one must begin by understanding the narrative chant of the 'origin' of the house as revealed by a ritual expert or man of knowledge (hataholi malelak). To this must be added the knowledge (and interpretation) of the particular uses of the different parts of the house. In comparison with this particular knowledge, which varies from domain to domain, the knowledge of construction is of a more general nature. Thus it was once a common practice to invite a master builder from one part of Roti to build a house in another. However, the majority of rituals performed in relation to this construction and the naming of the parts of the house after construction followed the traditions of the local domain.

My purpose in this paper is to provide an initial understanding of the house. Specifically, I am concerned with traditions of the house of the domain of Termanu as they are revealed in its narrative of 'origin' and in the ceremonies that are performed within it. My focus is more on cultural design than on physical construction - more on the ritual understanding of the house than on its 
architectural structure - and thus, specifically, on the nexus between image, object and location.

Since I cannot provide, in this paper, a detailed description of all parts of the house, I concentrate on an outline of some of its main features. In particular, I consider the fundamental orientation of the house and the location of key structures within this oriented space. My reason for this focus is to provide a comparative perspective. I want to identify some of the essential features of the Rotinese house that may relate to similar features of other traditional houses in eastern Indonesia and possibly more widely within the Austronesian-speaking world. I would argue that a notable characteristic of the eastern Indonesian house (and possibly that of most Austronesian houses) is its 'oriented structure'. Although this orientation may differ from society to society or even from locality to locality, features of this system of orientation bear family resemblances. These resemblances may pertain both to construction and to cultural design. The issue of the 'oriented house' thus relates to the wider issue of the transformation of symbolic coordinates and their various uses as ritual referents not just in eastern Indonesia but among Austronesian-speakers in general.

\section{The Origin of the Rotinese House: Textual Foundations}

The 'origin' of the first house is recounted in the most important of all Rotinese origin ritual chants. It can only be told guardedly with special hedges and intentional distortions because it reveals the primal sacrifice on which the initial construction of the house was based. This revelation explains the hidden design of the house and the relationship between the different parts of the house. This chant is supposed to be recited at the consecration - the 'making whole or full' (nakatema) - of a new house.

In Termanu, this canonic chant is identified with the chant characters Patola Bulan and Mandeti Ledo, the sons of the Sun and Moon. The various versions of this and other related chants suggest that all these narratives may have formed part of a long epic, now told only in assorted parts, that recounted the relations of the Sun and Moon (Ledo do Bulan) and their children with the Lords of the Sea and Ocean (Liun do Sain) and other creatures of the sea depths. In these narratives, the earth provides the middle ground for the interaction between these two complementary worlds and thus men become the beneficiaries of this relationship.

In the chant, the construction of the first house occurs only at the end of a long narrative (see Fox 1975:102-110 for a longer textual analysis of versions of this chant). Briefly summarized, the chant recounts the initial encounter of the sons of the Sun and Moon, Patola Bulan and Mandeti Ledo, with the 'Chief Hunter of the Ocean' and the 'Great Lord of the Sea', Danga Lena Liun and Mane Tua Sain, who, in Rotinese exegesis, are identified as Shark and Crocodile. These 
paired personages join together to hunt pig and civet cat and, when eventually they catch their prey, they decide to descend into the sea to perform the required sacrifice. There the sons of the Sun and Moon discover a new world of fire, cooked food, decorated houses, numerous essential tools and other cultural objects.

De ala tunu hai bei masu

Ma ala nasu oek bei lume

Nai lo heu hai ikon

Ma nai uma sini kea louk.
They roast on a smoking fire And they cook in boiling water In a house roofed with rayfish tails And in a home decked with turtle shell.

The sons of the Sun and Moon hide a portion of this cooked food and bring it back with them to the Heavens for the Sun and Moon, Bula Kai and Ledo Holo, to taste. In one version of the chant, the Sun and Moon propose to make war on the Lords of the Sea to obtain their wealth but this is discounted as impossible. Marriage is proposed instead as more appropriate so that the Sun and Moon may obtain what they desire as bridewealth from the Sea. In all versions of the chant, there occurs a long and remarkably similar formulaic recitation of the objects that make up this bridewealth. These objects include water-buffalo with crocodile markings and gold chains with snakes' heads, mortar and pestle for pounding rice and millet, tinder-box and fire-drill for making fire and also the tools for the construction of the house. The passage in the chant in which the Lords of the Sea give these objects follows:

Te ala bei doko-doe

Ma ala bei tai-boni.

Besak-ka ala fe bo pa'a bela

Ma ala fe taka-tala la.

Ala fe sipa aba-do

Ma ala fe funu ma-leo.
But still they continue to demand And still they continue to claim. Now they give the bore and flat chisel And they give the axe and adze. They give the plumb-line marker And they give the turning drill.

When these bridewealth negotiations are concluded, the chant shifts focus.

Besak-ka lenin neu poin

Ma lenin neu lain.

De besak-ka lakandolu Ledo lon Ma la-lela Bulan uman.
Now they carry everything to the Heights

And they carry everything to the Heavens.

Now they construct the Sun's house

And they design the Moon's home.

The work of construction, however, does not go well. Various trees are required for different parts of the house - the keka (Ficus spp.), the fuliha'a 
(Vitex spp.) and the lontar (Borassus sundaicus) — but they cannot be erected to stay in proper alignment.

Boe ma ala lo'o

Keka lasi do duak kala

Ma ala huma

Fuliha'a do teluk kala

Tao neu sema teluk

Ma tao neu to'a duak

Tao neu lo ai

Ma tao neu uma di.

Te lakandolu nai lain

Na ana kekeak leo dae mai.

Ma lakandolu nai dulu

Na lai leo muli neu.

Boe ma ala léa la tua tele

Ma ala lo'o la ai nalo

De ala lo'o na langa nalo

Ma ala tati na laka tele

Ala tao neu sema teluk

Ma ala tao neu to'a duak.

Ala tao neu uma di

Ma ala tao neu eda ai.

Te laole nai lain,

$\mathrm{Na}$ ana kekeak leo dae mai

Te lakandolu nai muli,

Na soko leo dulu.

Boe ma ala dodo neu dalen

Ma ndanda neu tein

Te keka lasi do duak ko

Ta dadi to'a duak

Ma fuliha'a do teluk ko

Ta dadi sema teluk.

Boe te ala boe dodo

Ma ala boe ndanda.
Then they hew

The two-leafed keka tree

And they chop

The three-leafed fuliha'a tree

To make into the two ridge-poles

To make into the three cross-beams

To make into the beams of the home

And to make into the posts of the house.

But they construct it on high

Yet it tilts toward the ground.

And they construct it on the east

Yet it leans to the west.

Then they draw the lontar palm bent-over

And they hew the wood straight

They hew looking upward

And they cut bending downward

They make them into the three cross-beams

And they make them into the two ridge-poles.

They make them into the house posts

And they make them into the tree ladder.

But when arranged on high

The house tilts toward the ground

When constructed on the west,

It slants to the east.

So they think to themselves

And they ponder within

The two-leafed keka tree

Will not become the two ridge-poles

And the three-leafed fuliha'a tree

Will not become the three cross-beams.

Thus they continue to think

And they continue to ponder. 
At this point in the chant, the telling falters and intentional distortions and omissions generally occur. Both chanters and commentators agree that it is dangerous to utter the next sequence. One version, however, reveals what other versions obscure. Without a model, the house cannot be constructed. For this reason, the Lords of the Sea, Shark and Crocodile, are summoned and sacrificed. Their skeletal structure is transformed into the house with the aid of a Heavenly Stick-Insect and Spider, Didi Bulan and Bolau Ledo.

Touk Danga Lena Liun

Ma ta'ek Man' Tua Sain

Ala taon neu uma di

Ma ala taon neu eda ai.

Besak-ka kalu kapa ledo ha'an

Ma dui manu au te'e na

Ala tao(n) neu sema teluk

Ma taon neu to'a duak.

Besak-ka Didi Bulan mai

Ma Bolau Ledo mai.

De lae: 'Deta ape.

De deta ape neu be

Ma lolo neu ndia'.

Boe te Bolau lolo ape neu be

Na ala solu limak neu ndia

Ma Didi deta ape neu be

Na ala fua lolo neu ndia.

Besak-ka sema teluk kala dadi

Ma to'a duak kala tola.

Besak-ka ala soe saiki ikon

Ma tati solo-bana langan.

Besak-ka lae: 'To'a duak'

Ma lae: 'sema teluk'

Losa faik ia boe

Ma losa ledon ina boe.
The man, Chief Hunter of the Ocean

And the boy, Great Lord of the Sea

They make him into the house posts

And they make him into the tree ladder.

Now his sun-heated buffalo sinews

And his dew-moistened chicken bones

They make them into the two cross-beams

And make them into the three ridge-poles.

Now Moon Stick-Insect arrives

And Sun Spider arrives.

Then they say: 'Dip spittle.

Where the spittle is dipped

There lay the planks [legs]'.

So where Spider lays spittle

There they rest the arms

And where Stick-Insect dips spittle

There they rest the legs.

Now the three cross-beams are made

And the two ridge-poles arise.

Now they incise a tail design

And they cut a head pattern.

Now they say: 'Two ridge-poles'

And they say: 'Three cross-beams'

To this day

And until this time.

The revelations of this origin chant provide an initial but only partial indication of the design knowledge (lela) that informs the knowledge of construction (ndolu). 


\section{Orientation and Exegesis}

The text of this chant - here based mainly on one of several recorded versions, that by the chantress, L. Adulilo - provides only the barest indications of the structure of the house. The chant contains references to ridge-poles and cross-beams, house posts and a tree ladder. References to a 'head' and 'tail' for the house indicate an orientation to the structure of the house. None of this, however, is sufficient to provide an architectural plan of the house or its layout.

Knowledge of the house is built upon this chant and begins with the exegesis that accompanies it. The chant is a composition in ritual language and the conventions of ritual language require the pairing of terms. These pairs are the starting point of an exegesis. As is often the case, the terms that make up various dyadic sets in the chant are drawn from different dialects of Rotinese (Fox 1974:80-83). Exegesis must begin with a 'translation' of terms into the dialect of Termanu and an explication of their meaning detached from the conventions of ritual language. Thus in the case of the set to'a//sema, to'a(k), the term for ridge-pole, occurs in ordinary speech in Termanu but sema is a term in western Rotinese dialect for what is called the papau(k), beam(s) in Termanu. The categories of two//three that are used to refer to these key structural features of the house (two ridge-poles//three cross-beams) are conventional numbers and are not to be taken literally. A house should have a single ridge-pole and four cross-beams but the numbers one//four do not form an acceptable dyadic set in ritual language. Yet because the origin chant emphatically refers to 'two $t o$ ' $a k^{\prime}$, ritual commentators provide an esoteric interpretation that identifies this second to'ak - in opposition to the to'ak at the top of the house - as a special beam beneath the planks of the house. Moreover, because the first $t o^{\prime} a k$ is conceived of as 'male', the second to' $a k$ is said to be 'female'. The wood chosen for each of these $t^{\prime} a k$ is supposed to be of the appropriate gender category. Probably more than any other example, this esoteric interpretation illustrates the way in which cultural design knowledge (lela) informs the knowledge of construction (ndolu).

Following a similar dual mode set by the conventions of ritual language, no creature can be named on its own. Hence in this origin chant, pig is paired with civet cat; crocodile with shark. In commenting on this chant, Rotinese insist that it was a pig that was hunted and sacrificed and that it was the crocodile, rather than the shark, whose body was used to create the house. There is, however, a further complexity in the association of the crocodile and the house. In the chant (and in other tales as well), the crocodile gives water-buffalo as bridewealth from the sea. The first water-buffalo from the sea, who are the progenitors of all water-buffalo, possess distinctive pied markings. These animals are described in Rotinese as 'buffalo with crocodile-body markings' (kapa ma-ao foek). There is thus an explicit association made between the body of the water-buffalo and the body of the crocodile, and the water-buffalo may be a sacrificial substitute 
for the crocodile. Hence the model for the structure of the house may be said to be that of a water-buffalo as well as a crocodile. Describing the house in this way disguises the nature of the original sacrificial act. Since, however, the crocodile takes on a human appearance in his excursions upon the land, the complete symbolic equation for the house links man to crocodile to water-buffalo.

The crucial feature of the first house, emphatically reiterated in the initial attempts at construction, is its oriented structure. The basic spatial coordinates of this orientation are those that are supposed to define all houses: east (dulu)//west (muli); right/south (kona)//left/north ( $k i)$; and above (lai)//below (dae). These coordinates are also the coordinates of the island itself and, as complementary pairs, are given conscious asymmetric valuation. Rotinese do this by citing a series of symbolic syllogisms. Thus, for example, the east//west coordinates represent the path of the sun. In one common syllogism, the sun is said to come from the east, hence the east is to be regarded as greater than the west. In another syllogism, north, which is the term for left, and south, which is the term for right, are equated but 'power' is said to come from the south, hence the south is given 'greater' categorical weighting than the north (Fox 1973:356-358;1989:46). A similar logic is applied to the categories of above//below. These categories are linked to the east and west directionals. On Roti, to go east is to go 'upward' and to go west is to go 'downward'.

In rituals, there exists a less explicitly articulated but nonetheless pervasive association of colours and qualities with the different directions. East is white (fulak) and associated with life; west is black (nggeo) and associated with death. The west is associated with the spirits of the dead and with the fertility they provide. There is thus a close association between death and decay and the sprouting of new life. The invariant life-giving qualities of the sun are associated with the east and the waxing and waning of the moon are associated with the west. The sun is identified as 'male' and is referred to as 'father' while the moon is 'female' and referred to as 'mother'. Their complementary relation is as a couple. Continuing this logic of multiple oppositions, the south is red (pilas) and associated with power and control while north is a blue-green-yellow (modo/momodo) and associated with sorcery and deception but also with curing. These associations are most clearly expressed in mortuary rituals and in an elaborate set of directional prescriptions for the orientation of the corpse and coffin (Fox 1973).

Yet another set of coordinates that are crucial to this system of orientation are the oppositional terms that link time and space. The term ulu means 'prior, earlier, former' in time and as a noun, uluk, refers to the 'first-born child'. By contrast, muli, which is the same term as 'west', means 'younger, later, subsequent in time' and as a noun, mulik, refers to the 'last-born child'. In 
Rotinese tales, it is the youngest child who is favoured by the spirits and it is the last-born male child that inherits the house.

The result of all this is an orientation system with auspicious directions, power points, and deep associations with special qualities, with time and with the human person. South and east are both auspicious male directions and, in a system of four quarters, the south-east represents the most auspicious of power points. The land of the dead is located to the west but it is also the direction of the spirits whence fertility derives. The north is the direction of sorcery but also of marvellous contrivance. During the colonial period the Dutch were identified with this direction.

In the chant of the origin of the house, a further coordinate is announced only when the construction of the house is achieved. This is the distinction between head (langa) and tail ( $i k o$ ), which can only be spoken of after the sacrifice of the crocodile. On Roti, this distinction is superimposed on the east - west coordinate and, in cultural terms, this distinction provides the 'setting' for the proper orientation of all houses. Every house has a 'head' which should look to the east and a 'tail' which should be turned toward the west (see Figure 1). The ridge-pole ( to' $^{\prime}$ ) of the house, when properly erected, follows this alignment. Houses, however, are man-made structures and can be put up in any order. Any house with its head turned in the wrong direction courts misfortune.

The same categories apply to the island of Roti as a whole. The island is spoken of as having its 'head' in the east and its 'tail' in the west. One goes upward toward the 'head' of the island and downward toward its 'tail'. Right and south are therefore synonymous as are left and north. The implication of these categories is that Roti itself is an immense crocodile floating with its head raised toward the east. The directional coordinates transcend as well as encompass the order of the house.

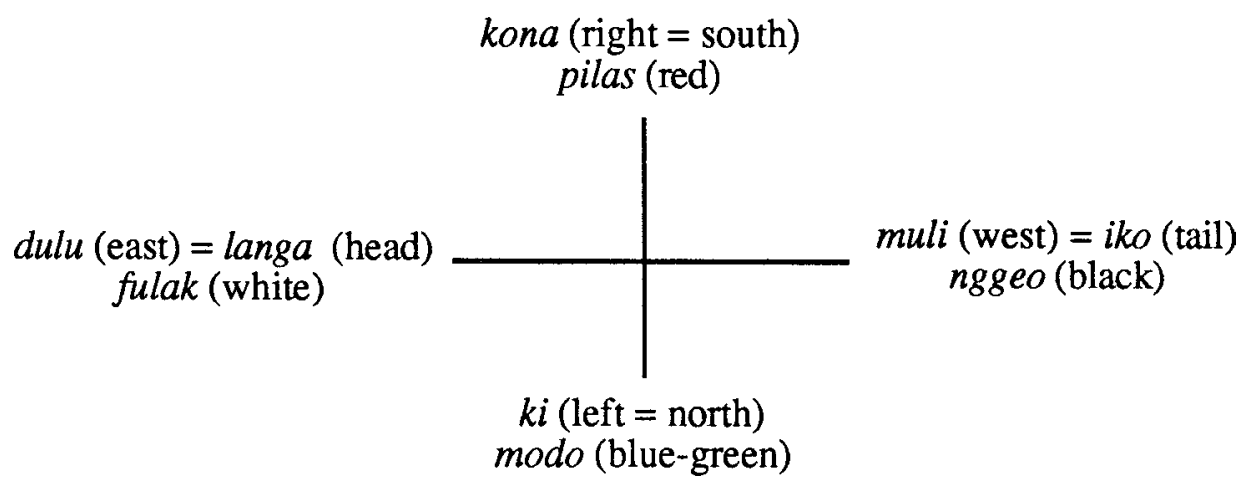

Figure 1. Directional coordinates and their symbolic associations

This orientation system is coherent, embedded in everyday speech as well as in ritual language, and consciously and sometimes explicitly articulated. 
During my first fieldwork on Roti, after I had recorded, transcribed and begun to gather exegeses on the chant of the origin of the house, Mias Kiuk, the elder who had more or less adopted me as his son, in exasperation at my probing of what was obvious, got down on all fours and told me to look carefully at where his head, his ribs, his legs were. This, he felt, was sufficient to make clear the structure of the house.

The same model was once given explicit expression in the division of labour in the construction of the house. During fieldwork, I was informed only of a threefold division among the builders of the house based on the 'body' of the house: head, middle and hind-end or tail. Van de Wetering (1923), writing about the Rotinese house on the basis of his experiences in the early 1920s, reports a similar threefold division but a far more detailed subdivision of responsibilities (see Table 1). At that time a distinction was made between the master builder (ndolu ina) and his subordinates (ndolu anak). The master builder was always assigned to the 'head' of the house and was known as the 'builder of the head of the house'. A second builder was assigned to the middle of the house and, according to van de Wetering, had two assistants who were designated as the 'chest and upper back builders' and another two assistants assigned to work on the sections of the house on either side of the ladder. These assistants were called the 'shoulder builders'. Finally there was the builder assigned to work on the end of the house. He was referred to as either the 'tail' or the 'hind-end builder' and was assisted, in turn, by two workers who were the 'hind-leg builders'.

\section{Table 1. Builders assigned to the construction of the house}

\begin{tabular}{|c|c|c|}
\hline I: & 1. ndolu uma langgak (ndolu ina) & builder of the head of the house (master builder) \\
\hline \multirow[t]{4}{*}{ II: } & 2. ndolu tena dalek & builder of the inner middle \\
\hline & 3. ndolu tenek & builder of the chest \\
\hline & 4. ndolu nggoti-haik & builder of the upper back \\
\hline & $5 / 6$. ndolu aluk & builders of the shoulders \\
\hline \multirow[t]{2}{*}{ III: } & 7. ndolu ikok (buik) & builder of the tail (hind-end) \\
\hline & 8/9. ndolu sakibolok & builders of the hind legs \\
\hline
\end{tabular}

This ninefold division of labour is an ideal schematic representation of the house as a body. On Roti, all such 'total representations' are supposed to consist of nine elements. Moreover, according to van de Wetering (1923:455-458), each builder received a corresponding division of meat of animals sacrificed for ritual purposes in the construction of the house.

With the knowledge of the Rotinese house as an oriented body and with an understanding of the associations of the Rotinese system of orientation, it is possible to consider, in more detail, the layout of the house.

\section{The Internal Structure of the Rotinese House}

From the outside, the traditional Rotinese house looks like an immense haystack (see Figure 2). A thatch of lontar leaves or alang grass extends 
downward to within a metre or so of the ground. Enclosed within this enveloping roof is a complex three-level structure. To enter, one must crouch beneath this thatch at its midpoint. Entry is only from the north or south, never from the east or west.

The question of the direction of entry to the house was in fact a contested, historical issue on Roti about which van de Wetering provides important information. Symbolically, in Rotinese conceptions, the south is unquestionably superior to the north and, for that reason, entrance to the house ought properly to be from the south. However, during the colonial period, entry was also permitted from the north since this was the quadrant of the Dutch whose power the Rotinese acknowledged. In explaining that entry was originally only from the south but later was also from the north, van de Wetering cites the Rotinese syllogism of the period: "The north is the same as the south but the Company [originally the Dutch East India Company] comes from the north, therefore the north is greater than the south' (van de Wetering 1923:471-472; see also Jonker 1913:613). This acknowledgement of Dutch power did not effect a wholesale change in the direction of entry but at least allowed an alternative possibility in the system.

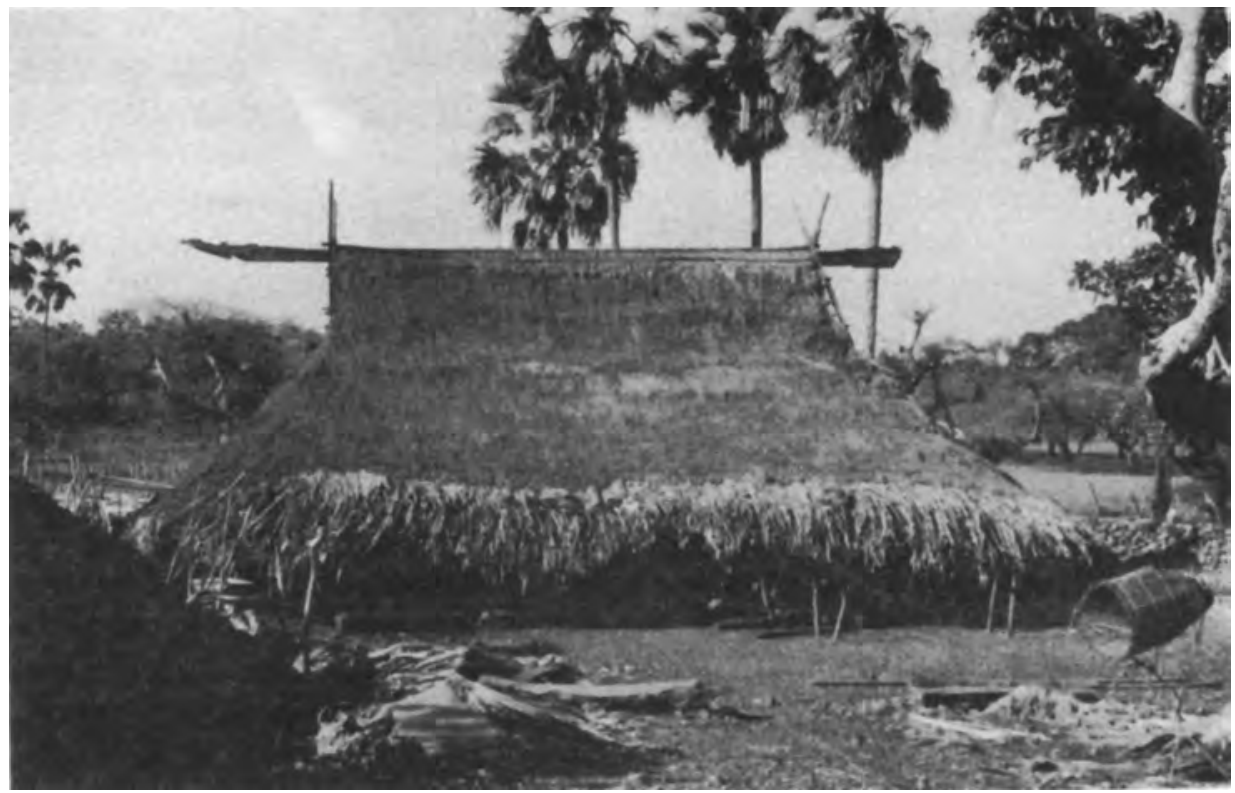

Figure 2. A traditional Rotinese house

Houses on Roti are classified according to the number of their main posts ( $\mathrm{di}$ ). Thus there are - or were - 'four-, six- and, in rare instances, eight-post houses' (uma di-hak, di-nek and di-faluk). These posts are the critical support structures of the house and they must preserve the same order as the trees from which they 
were cut with their bases (huk) planted in the ground. Similarly, house beams, and especially the ridge-pole, must be oriented with their bases at the tail of the house and their tips toward the head. This order is a fundamental requirement of auspicious construction practice.

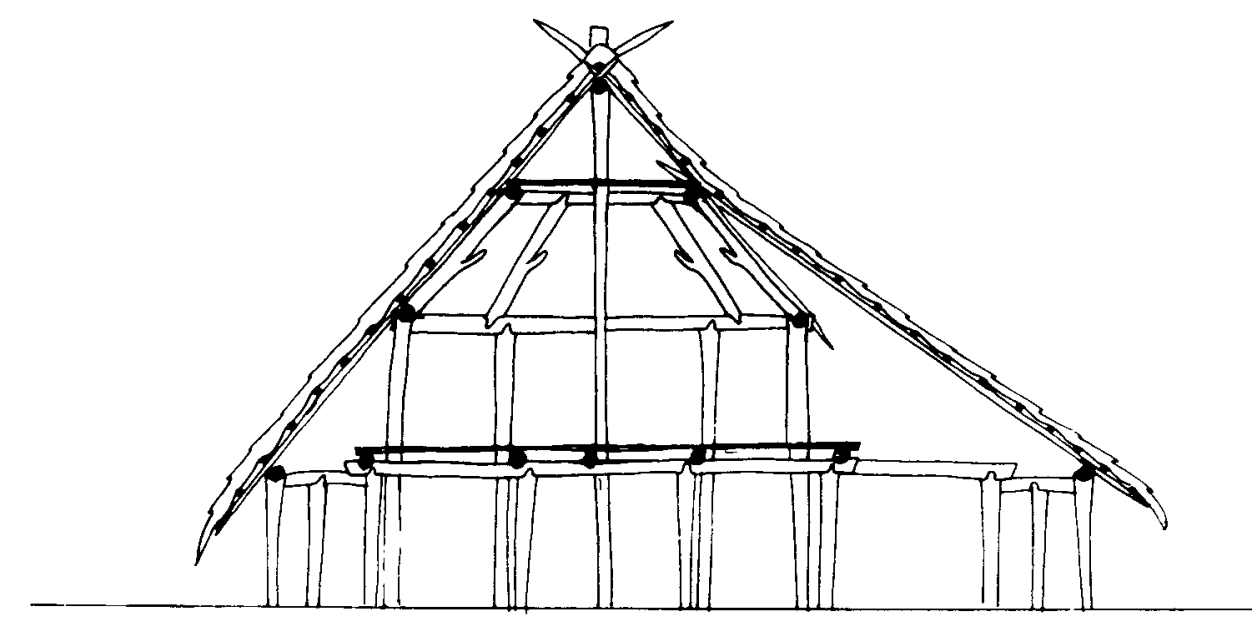

Schematic representation of the house (side view)

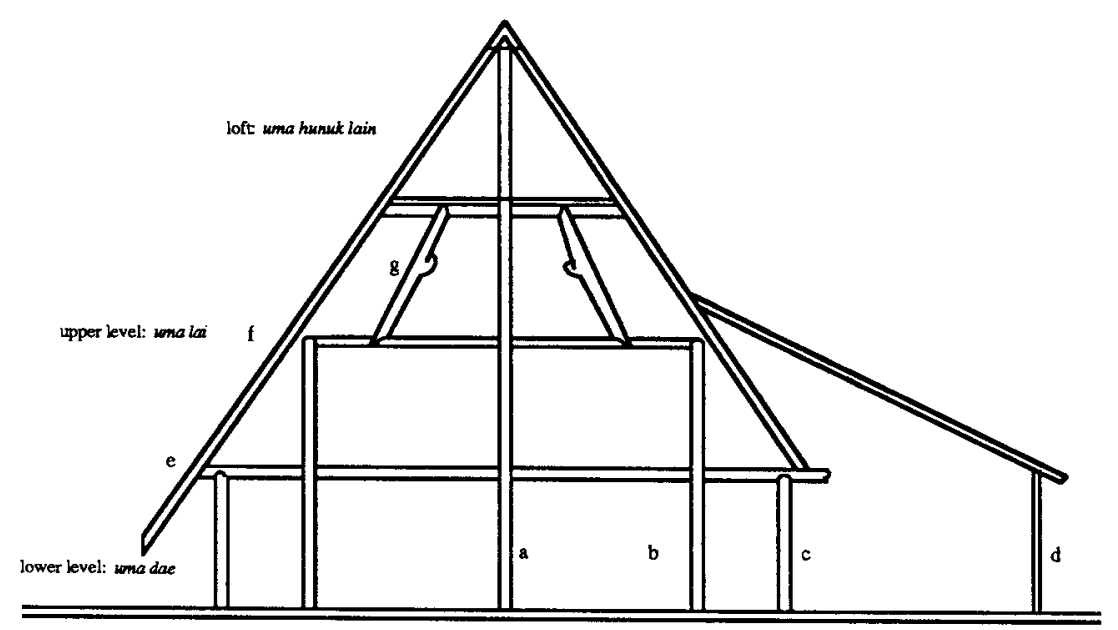

a di $t^{\prime} a k$ posts supporting the ridge-pole ( $t o^{\prime} a k$ )

b di papauk: posts supporting the cross-beams (papauk/semak)

c di lungus. posts supporting the floor-beams (lungus)

d di istuk: post supporting the perimeter roof

e lungus: beams supporting the floor boards

f papauk: cross -beams (rimal language - semak)

$\mathrm{g}$ dengak: struts that support the floor-beams of the loft

Figure 3. The classification of levels of the Rotinese house

The basic minimal house structure is a 'four-post house'. The six-post house is essentially a four-post house with the addition of two more posts set at the 
western or tail end of the four-post structure. Larger houses are thus extensions on a basic form. All houses involve a science of construction (ndolu) based on proportions of an odd and even number of elements. Thus, for example, a 'sixor eight-post house' is not just a longer house but is also raised higher off the ground. The ladder must have an odd number of steps. For a four-post house, the ladder should have seven steps; for a six-post house, nine; and, for an eight-post house, eleven. Similarly, although the total number of roof spars must be odd, there must be an even number on the left side of the house and an odd number on the right side.

As with many Rotinese forms of classification, the levels of the house may be considered as either a dichotomy or as a trichotomy (see Figure 3). Conceived as a dichotomous structure, the house consists of a 'ground level' (uma dae) and a raised 'upper level' (uma lai). This division is based on coordinates, dae//lai, 'above'//'below' or 'earth'//'sky' and the entire raised portion of the house is regarded as a single unit. Conceived as a trichotomous structure, however, the 'upper level' is seen to contain the loft (uma hunuk lain) which can only be reached by an internal ladder from within the upper level itself. In this conception, the first raised level of the house forms a middle world between the loft and the ground.

Humans as well as animals, particularly dogs and pigs, occupy the space at the ground level of the house. This whole area is known as the finga-eik. A number of raised resting platforms (loa-anak) are set at this level and used for everyday activities. The head of the house occupies the 'head' or eastern-most platform and when guests visit, they align themselves in a rough order of precedence from east to west in relation to their host.

The organization of space at the first raised level of the house (see Figure 4) provides the major conceptual distinctions within the house. Here, again, classification is both a dichotomy and a trichotomy. Conceived as a dichotomy, the larger eastern half of the house is referred to as the 'outer house' (uma deak); the lesser western half of the house, separated from the 'outer house' by a partition, is called the 'inner house' (uma dalek). As a trichotomy, the 'outer house' is divided into 'head' (uma langak) at its far eastern end and 'inner middle' (tena dalek) or 'inner chest' (tene dalek) while the 'inner house' (uma dalek) remains conceptually undivided.

A ladder (heda-huk) is set on a flat stone base (bata tatabuk) under the roof and roughly in the middle of the house, facing the entrance (see Figure 5). It leads from the ground level up into the 'outer house'. The rules of proper order require that the first step from the ladder into the 'outer house' be with the right foot and the same rule for auspicious entry applies as one goes from the 'outer house' to the 'inner house'. The ladder itself can be drawn up and the entrance doors on either side of it can be closed to seal off this level from the ground. In 
speaking of privacy, Rotinese remark that one does not know - nor does one inquire - what someone does inside a house when the ladder is drawn.

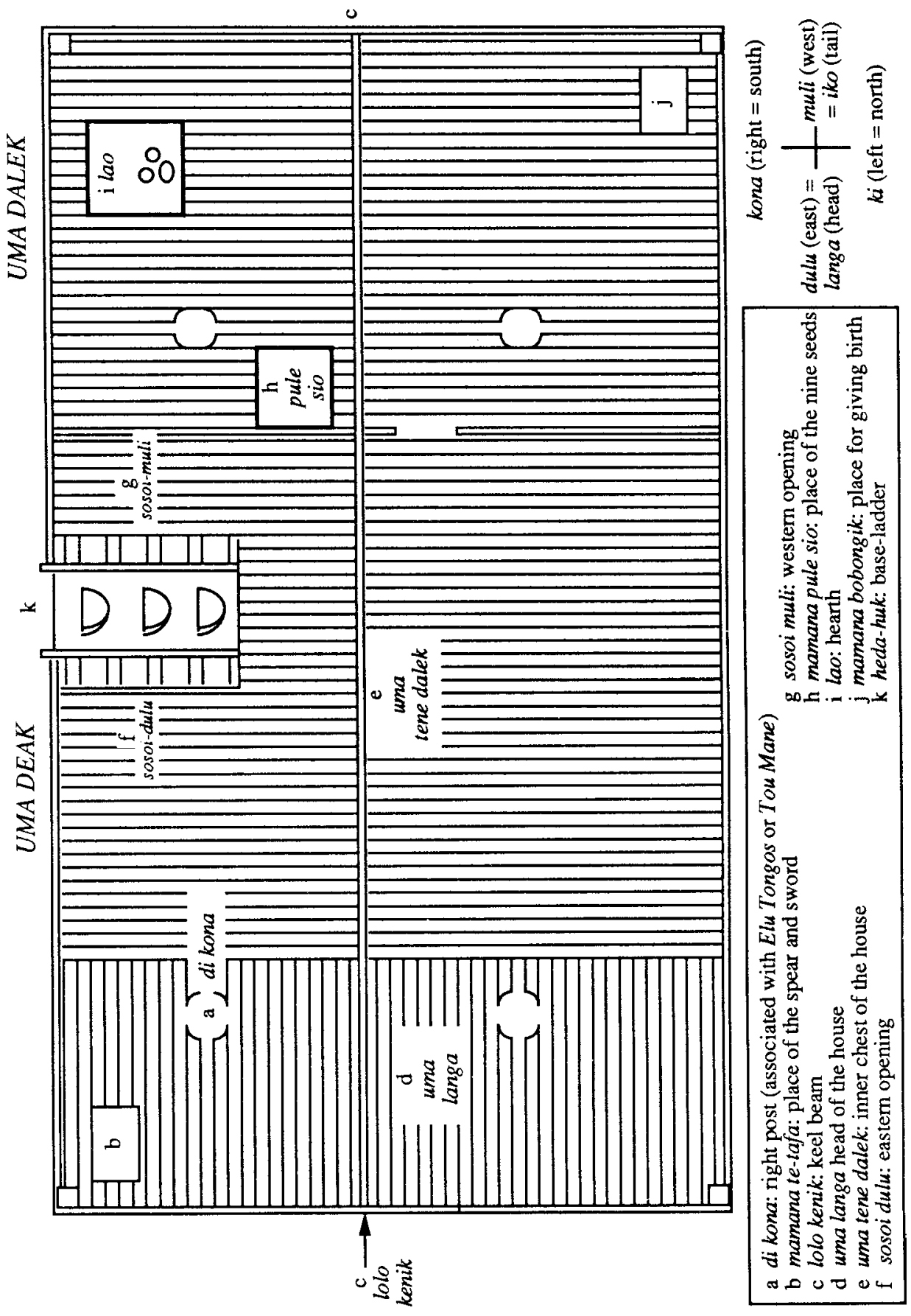

Figure 4. Plan of interior of a Rotinese house 
The raised level of the house is a private area. Only family members, relatives and guests at certain rituals are allowed up into the house. The 'inner house' is an even more intimate precinct than the 'outer house'. In the 'inner house' is another ladder that leads up into the loft, which is the most closed and intimate section of the entire structure.

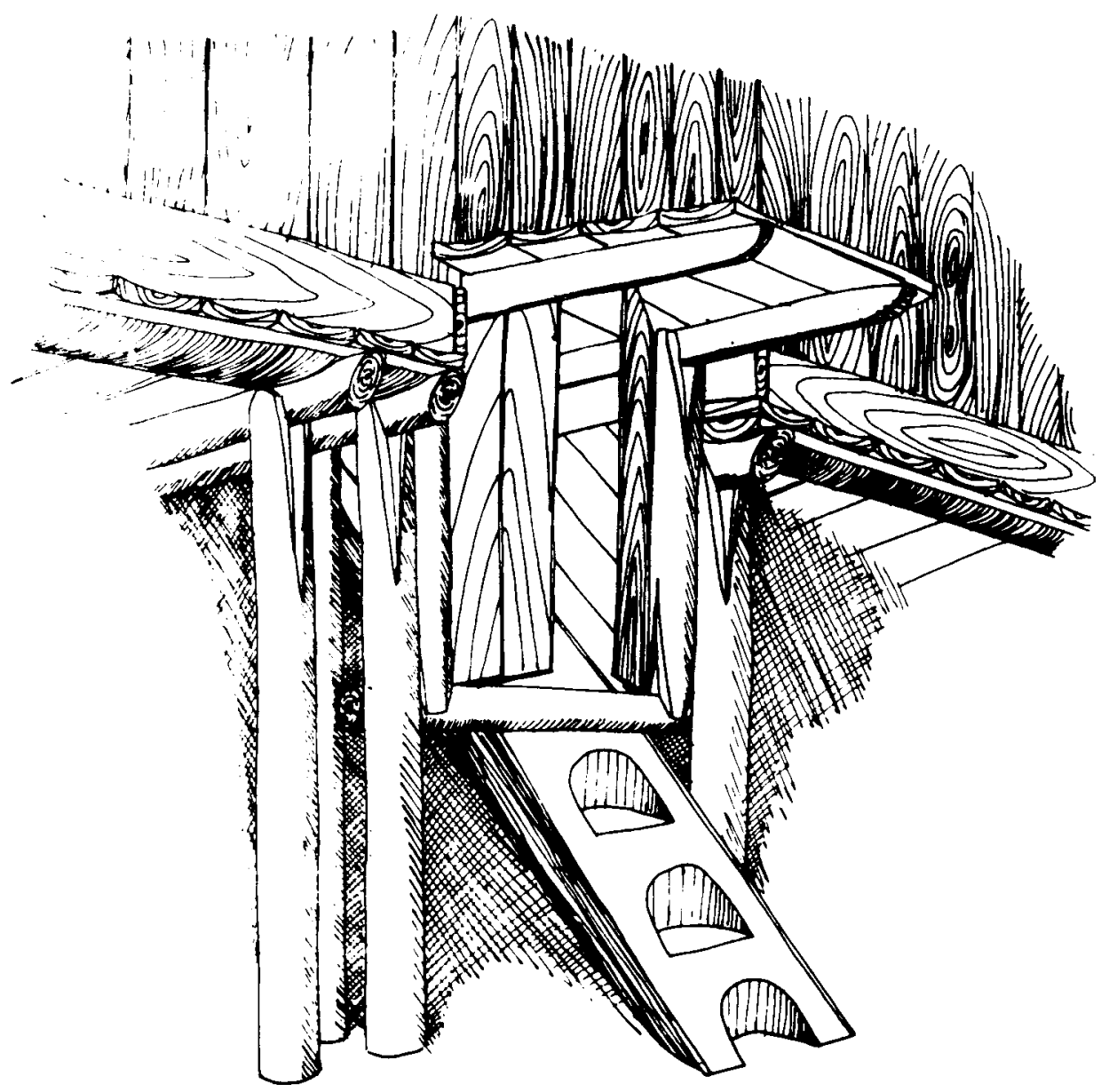

Figure 5. Sketch of the ladder (heda-huk) leading into the upper house (uma (ai)

In marriage ceremonies, the close female relatives of the groom receive the bride when she is escorted to her husband's family house. There they wash her feet before she ascends the ladder into the house. The women then escort her into the 'inner house' and carefully place her hand on different objects in this part of the house. In traditional ceremonies, a marriage chamber was prepared for the couple in this inner precinct. 
When a man has built a house for his wife and is able to move from his family house, he surrenders all access to the house to his wife. He can offer guests nothing if his wife is not present and he can only gain access to what is stored in the loft through his wife. By the same logic, if an unrelated man enters under the roof of a house when only the wife is present, he can be accused of adultery and heavily fined. When visiting a house, one must call out for permission to enter before stooping under the thatch.

The distinction between inner (dalek) and outer (deak) sections of the house is given marked gender associations. Although the house as a whole is conceived of as female and only one woman may have jurisdiction over it, the closed 'inner house' at the western end of the building has the strongest female associations. This precinct is reserved as the sleeping place for unmarried girls of the household. By contrast, adolescent boys should sleep in the 'outer' section of the house.

The gender associations between the 'inner' and 'outer' sections of the house imply a clear separation between brothers and sisters. Hence, when the children of a brother and sister marry, the marriage is described as a reunion of the two parts of the house. Uma deak leo uma dalek, uma dalek leo uma deak: 'the outer house goes to the inner house, the inner house goes to the outer house'.

In the inner house are located the cooking fire, a water jar, and a large sack-like basket (soko) of harvested rice which stands for the 'nine seeds' (pule sio) of the agricultural cult. ${ }^{3}$ The close physical and symbolic association of rice, water and the hearth - all clustered in the female precinct of the house - is of critical importance since these elements serve to define the house as a commensal unit. A ladder leads from the 'inner house' into the loft which is a further, elevated extension of this inner sanctum, where more food and valuables are stored. Also located in the loft is a vat of lontar syrup, the 'great spirit jar' (bou nitu inak), which is never supposed to be empty. According to pre-Christian traditions, the spirits of the dead have their physical representations as specially shaped lontar leaves (maik) which are hung in the loft and are there given appropriate offerings. A house with such spirits is or was acknowledged as an uma nitu, a 'spirit house'. (Since the lastborn son inherits his parents' house, access to the spirits within the house passes to this youngest child, thus enhancing the strong associations - muli/mulik — of the last-born with the spirits of the west.) Births, however, are also arranged to take place in the inner house' in close proximity to the spirits, and women and children of the family who are seriously ill retreat to this part of the house to seek recovery.

A prerequisite for the well-being of a house is that it be inhabited by a cat. Such a cat is called the 'cat in the upper house' (meo nai uma lai). This cat is identified with the woman of the house in the same way as a man may be identified with his hunting dog. If a woman were to leave her husband, this can 
only be referred to, in polite conversation, as the departure of the 'cat in the upper house'. To retrieve his wife, a man must first ritually cleanse the ladder of his house before seeking to woo his wife to return.

The 'outer house', with its basic division into 'head' and 'inner middle', also contains other named locations. The most important ritual position in the 'outer house' is the post located at the south-eastern section of this precinct. This is called the di kona, the 'right/south post', the first and foremost foundation post of the house. It is dedicated to the Lord of Lightning and of the Rainbow who is known, in Rotinese, as Elu Tongos or, alternatively, as the Tou Mane, literally the 'Male-Man'. This post is believed to be the stabilizing point that secures the house to the earth. It is the first post that is set in the ground during construction and should be accompanied by offerings to the Earth and to Elu Tongos. ${ }^{4}$ As the foremost post, this 'right/south post' marks the beginning and origin of the construction of the house. A red cloth is often wound around this post and a container of what is described as 'reddish' coconut oil is supposed to be hung on or near it and used to anoint the post at times of severe storms and typhoons. Formerly, sacrifices and divination by means of a spear were also carried out at this post.

The outer house holds male implements of various sorts. The spars offer convenient places to hang these implements; for example, the initial payment of bridewealth consisting of the spear and sword given by the groom's side to the bride's family. In the ceremonial presentation of these male tokens, the spear and sword are supposed to be carried into the outer house and hung from the spars in the south-eastern corner of the 'head of the house' near the right post.

There is a cryptic ritual language saying:
Ala lolo dulu no muli
They lay the beams east and west
Ma ala ba ki no kona.
They lay the cross boards north and south.

This saying is cited in reference to the planks in the 'inner middle of the house' which are supposed to run in a north-south direction in contrast to the other beams of the house, particularly those at the 'head of the house' which run east-west. One knowledgeable commentator referred to the north-south floor planks as bak, which in Rotinese can mean 'lungs' but could also be a technical term from the verb/adverb - $b a$, meaning 'to lay crosswise'. Interpretations based on folk etymologies and on basic terms of similar sound shape are recurrent features of local exegeses.

The inner middle of the house (uma tena dalek) is also referred to as the 'inner chest' of the house (uma tene dalek). The names of the lengthwise floor planks in this section of the house extend the body imagery of the house. On either side of the floor planks called the 'inner chest planks' (papa tene dalek) are the 
right and left 'rib planks' (papa kaiusu ki/kona). From this conceptual vantage point, the inside of the house is even more explicitly defined as the inside of a 'body'. (Figure 6 shows the ladder, levels and division within the house.)

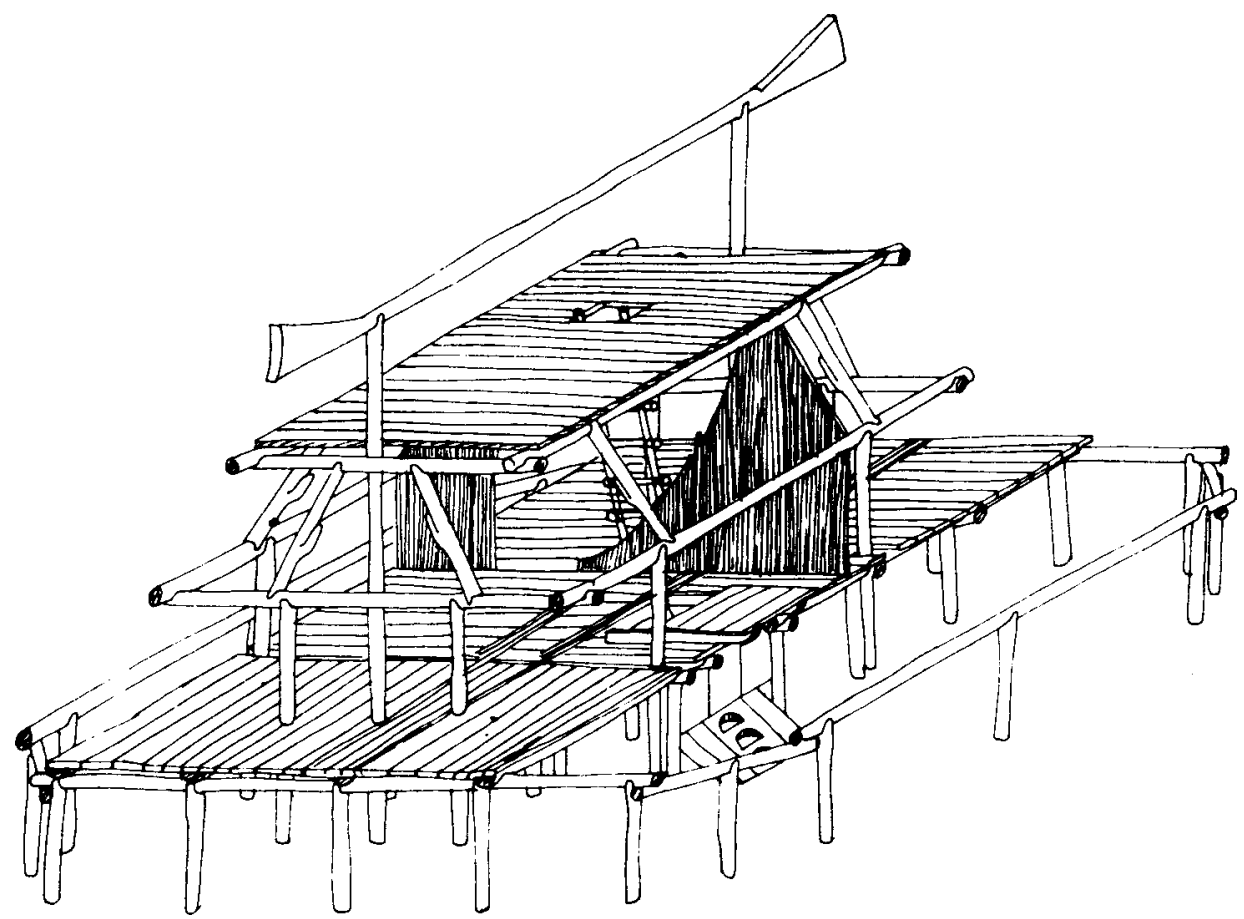

Figure 6. Schematic representation showing the ladder, levels and division within the Rotinese house

Not only is the house conceived of in terms of the physical categories of a 'body'; its internal structure also conforms to the major categories that define the 'person'. In Rotinese, dale( $k$ ) refers to the inner core of a person, the seat of both cognition and emotion. Thus serious thoughts, reflections and judgements are regarded as coming 'from inside' (neme dale-na) or as 'thought from within oneself' (afi nai dale-na). Similarly in Rotinese, there are numerous compound expressions for emotional states based on the category dale-: dale-malole, 'to be good hearted, friendly'; dale-hi, 'to desire intensely'; nata-dale, 'to be glad, overjoyed'. In contrast to this use of dale is the conscious, manipulative use of words (dede'ak) in which Rotinese delight. This verbal play is part of an external persona and does not belong to the inner core of the person (Fox 1973: 343-346). Like the 'inner house', the inner person is intimately distinguished from what is publicly expressed. 


\section{Internal Structures and the Performance of Rituals in the House}

Running down the middle of the house beneath the floor planks is a supporting beam called the 'keel beam' (lolo kenik). According to the science of construction, there must always be an odd number of lolo with the lolo kenik as the middle beam of this set. Interpretation of the kenik introduces another set of metaphoric associations. Thus, for example, a common Rotinese saying asserts that the husband is the 'keel' of the house and the wife is its 'rudder' or 'steering oar' (touk uma kenik ma inak uma uli). Despite this notion of a 'keel', there is relatively little ship imagery applied to the house as a whole. However, the area demarcated by this 'keel beam' is reserved for the performance of the mortuary rituals. The principal ritual function of the 'keel beam' is to align the coffin within the house during the period of ritual mourning before burial (Fox 1973:359). In ritual chants, the coffin is described as the 'ship' of the dead and is pointed 'eastward' inside the house before it is taken out and lowered into the ground 'to sail' in a westward direction. A cloth given by the mother's brother to his deceased sister's child is supposed to represent the sail of this ship of the dead.

In mortuary rituals, the open coffin is laid out in line with the 'keel beam', and a covering cloth known as the tema lalais, the 'broad cloth of heaven', is hung above the coffin. The final ritual act of the mother's mother's brother for his deceased sister's daughter's child is to take down this cloth after the coffin has been carried out of the house and to throw it onto the outside thatch of the house, thus ending a life-giving relationship that began two generations before.

Ship imagery is confined chiefly to rituals that relate to the coffin. In the interpretation of the house based on the chant of its origin, the 'keel beam' is said to be the second ' $t o^{\prime} a k^{\prime}$ ' or ridge-pole alluded to in the chant. This is an esoteric identification because the 'keel beam' does not bear the name 'to' $a k$. A dialectic of gender oppositions is called into play here. In relation to the steering oar, the 'keel beam' is considered to be 'male' yet in relation to the ridge-pole, which is aligned directly above it, this beam is supposed to be 'female'. According to the science of construction, the wood for the ridge-pole should come from a male lontar palm whereas the wood for the 'keel beam' should come from a female lontar. This arrangement is consistent with the overall gender symbolism of the house and thus overrides the implications of the incidental symbolism of the ship.

On either side of the ladder that leads up into the 'inner middle' of the 'outer house' is a demarcated space known as the 'eastern opening' (sosoik dulu) and the 'western opening' (sosoik muli). These two 'openings' are actually platforms that constitute complementary positions within the house. They are not, however, of equal size since the western 'opening' is supposed to be wider than the eastern 
'opening'. The two locations are a much used space within the house. Often during negotiations or discussions taking place at ground level, women of the house (who are not supposed to be formally present) sit at these 'openings', with their feet hanging down, and listen to what is being said by hosts and guests below them.

When the ladder is drawn up and the house is closed, these two 'openings' have another function. According to the traditions of the house, the husband sleeps on the 'eastern opening'. A wife is supposed to sleep on the 'western opening' and when they make love, the husband should move to the wife's 'opening'. Often, however, and certainly whenever there are visitors, the husband sleeps on the easternmost resting platform at ground level. According to the memories of older Rotinese, a young man who was considered a promising suitor was formerly invited into the house and allowed to spend the night on the 'western opening'. From there he could communicate with a daughter of the family who was separated by the partition dividing the 'inner house' from the 'outer house'.

In mortuary rituals, these places take on another function as ritual locations for the maternal affines (Fox 1971:241-243; 1988). The ritual position of the mother's brother (to'o-huk) is at the 'eastern opening' and that of the mother's mother's brother $\left(b a^{\prime} i\right.$-huk) at the 'western opening'. All guests who come up into the house must pass between these two affines to approach the coffin and mourn the deceased. Whether or not they are physically present at these positions for the duration of the ceremonies, the cooked food specifically given to these affines must be laid at these places within the house. Only when this cooked food has been placed at these locations, to feed these affines, can the funeral feast begin and other guests be fed.

Inside the house - roughly at mid-level height - on the first raised level of the house are the cross-beams (Termanu: papauk; ritual language: semak). These beams form a rectangular structure around the house. Struts (dengak) from these cross-beams support the floor of the loft. The long spars, to which the roof thatch is tied, extend down from the ridge-pole to roughly a metre from the ground. These spars, called dodoik, rest on the outer edge of the cross-beams. In terms of the imagery of the house as a body, these spars would appear to be ribs (see Figure 7). The spaces between them are called latik. These latik are conceived as different 'paths' (enok). They are aligned as an ordered set of pathways in relation to the internal structure of the house and each is given a name in association with a particular spar. In the non-Christian traditions of Roti, offerings are supposed to be made at the spars of these named paths to ensure the welfare of the creature or activity they preside over. The basic ordering of these 'paths' is similar throughout Roti but since houses may be of 
different lengths, and therefore may differ in the number of these 'paths', the actual arrangement of these paths may be more or less elaborate.

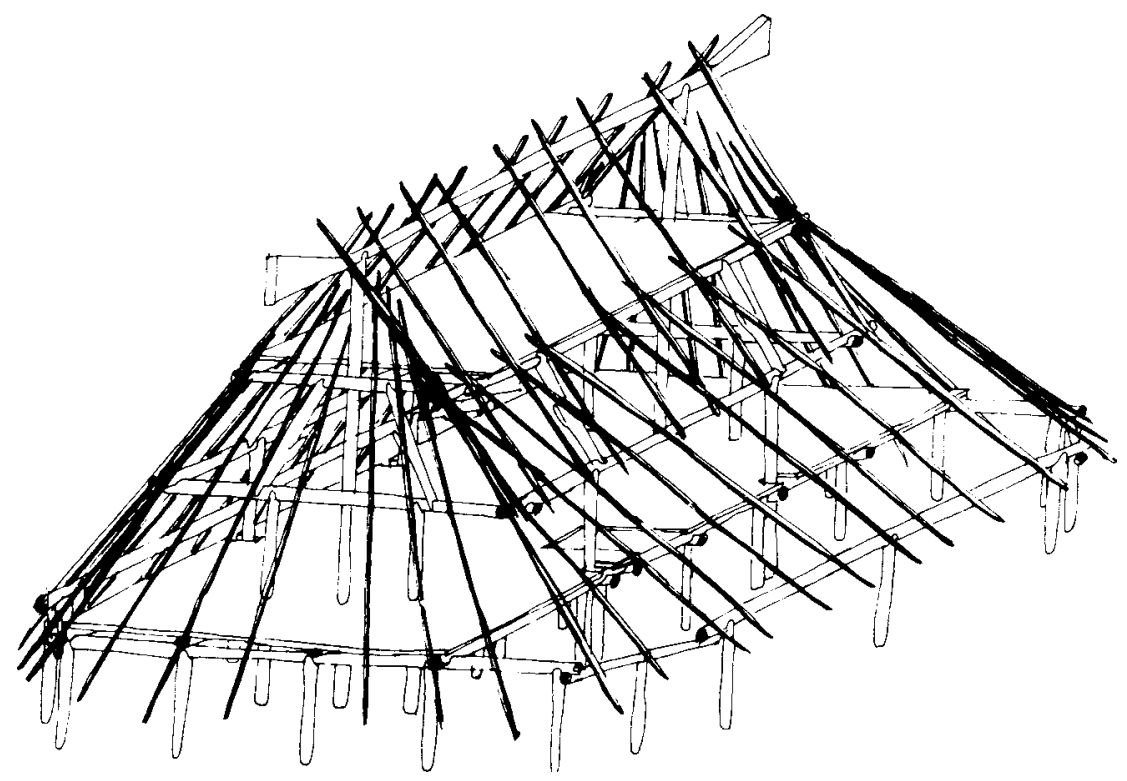

Figure 7. The spars of the traditional Rotinese house

Proceeding from the eastern end of the house, which constitutes the 'outer house', to the western end of the house, which forms the 'outer house', the ordered list of the names of these paths is as follows:

\begin{tabular}{|c|c|}
\hline Path (Enok/Latik) & Gloss \\
\hline lati Elu Tongos & path of Elu Tongos (Lord of Lightning) \\
\hline lati touk & path of the man \\
\hline lati kapa & path of the water-buffalo \\
\hline lati ndala & path of the horse \\
\hline lati bi'ik & path of the goat and sheep \\
\hline lati sosoi dulu & path of the eastern opening \\
\hline lati nusak (lelesu) & path of the domain (entrance) \\
\hline lati sosoi muli & path of the western opening \\
\hline lati bafi (bana) & path of the pig (animal) \\
\hline lati pule sio (lakimola) & path of the nine seeds (lakimola) \\
\hline lati ule oe & path of the water jar \\
\hline lati lao & path of the hearth \\
\hline lati ana $f^{\prime} o$ & path of the daughters \\
\hline lati bobongik & path of birth \\
\hline
\end{tabular}


The system is expandable or contractable. Paths may be designated by various alternative names. Thus, for example, the 'path of birth' and the 'path of the daughters' may form a single space. Similarly, while all houses should have a 'path of the nine seeds', some would argue that a house should also have a 'path of the water jar'. Together they may constitute one path. On the eastern side of the house, the 'path of the horse' and the 'path of the water-buffalo' may form a single 'animal path' as on the western side of the house. In theory, the horse and water-buffalo set could also be expanded to include a separate 'path' for goats and sheep $\left(b i^{\prime} i\right)$ as is the case in other domains (see Figure 8).

The system of the latik outlines an order to the house following a differentiation between female and male activities associated with the 'inner' and 'outer house'. At the western end of the house is the sleeping place of the daughters of the house, but it is also the place where a woman gives birth. To facilitate this birth, she is supposed to grip the two spars (dodoik) that frame the 'path of birth'. This location for giving birth is opposite to the hearth and, as is common throughout the region, it is here a woman must undergo a period of 'cooking' after giving birth. The hearth is a defining feature of the woman's side of the house. ${ }^{5}$

At the eastern end of the house is the 'path of the man'. It is located beside the 'path of Elu Tongos', the 'Male-Man' (Tou Manek), which is associated with the power of lightning, of storms and of the weapons of male prowess. Significantly, when a man becomes ill, he sleeps near the 'right post' in line with the 'path of the man'; when a woman is ill, she confines herself at the opposite corner of the house. Formerly, Rotinese insist, offerings for men were made at the south-east corner of the house and for women at the northwest corner.

The domestic animals are also assigned positions within this male and female space. The pig is assigned to the woman's side of the house whereas the horse and water-buffalo (as well as goats and sheep) are accorded one or more paths on the man's side of the house. This division parallels a distinction in affinal exchange gifts: water-buffalo, goats, sheep (and horses among high nobles) are defined as 'male' goods and given by wife-takers to wife-givers in exchange for pigs which are defined as 'female' goods (Fox 1980a:117-118). There are a variety of other reasons given for this assignment. Men spend considerable time caring for their herd animals and personally identify with their horses. Women, on the other hand, are charged with feeding household pigs and, therefore, the pig's feeding trough is supposed to be set in the courtyard in front of the west side of the house. The succinct and somewhat curious Rotinese expression that is cited to denote this relationship is: 'The pig [always] stomps on the woman's foot' (Bafi molo ina ein) implying that pigs are almost insatiable and, in their impatience for food, they invariably punish their feeder. 
Memories of Ridge-Poles and Cross-Beams: The categorical foundations of a Rotinese cultural design

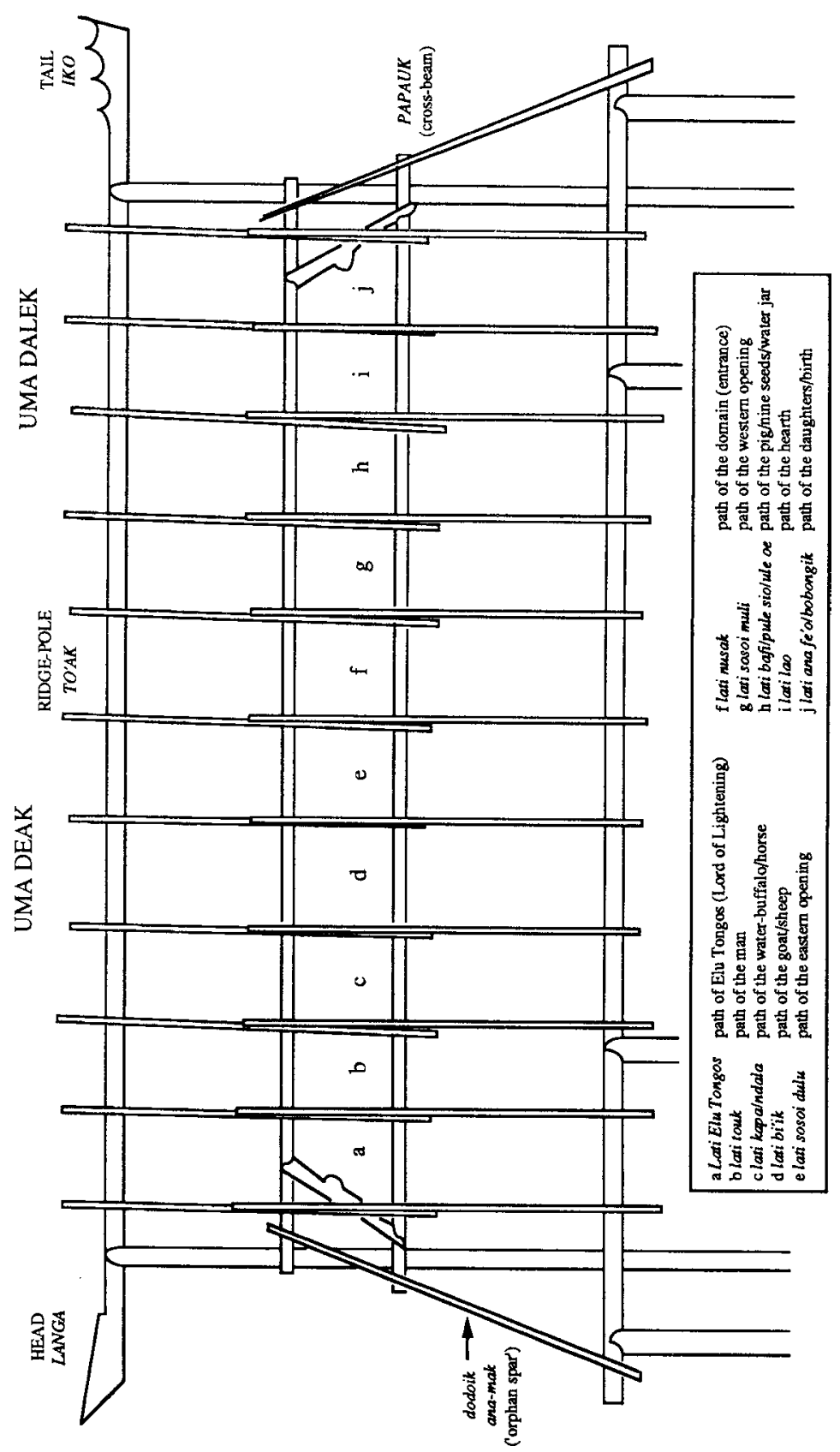

Figure 8. Schematic representation of the paths of the house

The cat also has a place in this system since the four spars at each corner of the house are called 'cat spars' and are associated with the 'cat in the upper house'. A close Rotinese friend, living as an elder bachelor after having been deserted by his wife, took me into his house to show me that one of the 'cat 
spars' of his house had been nailed where it should have been tied. He cited this improper construction as a cause of his marital difficulties. The dog, too, has its place. Dogs are opposed to cats in Rotinese complementary categorization. Dogs are 'male'; cats are 'female'. Unlike the cat, which is supposed to remain in the house, the dog is never allowed to mount the ladder into the house and is thus always confined to ground level.

At each end of the house, but especially at the front of the house where the roof extends outward, there is a spar that fills the corner gap. It extends only half the length of the other spars, fitting between them in the corner. This is called the 'orphan spar' (dodoi ana-mak), which is an apt description of its structural position. Interpretation of this spar does not, however, focus on its technical function in construction. The concept of 'widow and orphan' is metaphorically elaborated in Rotinese philosophy to stand for the conditions of bereavement, dependence and mortality (Fox 1988:184-185). As such, the 'orphan spar' is regarded as a necessary feature of the house and as a reminder of the human condition.

Just as the house has a 'head', 'tail', 'chest', 'ribs', and 'lungs', it also has a 'neck' (botok), the space just under the top of the roof. On top of this 'neck' are set an odd number of 'neck-braces' (lange), wooden cross-bars that are run along the crest of the roof to hold the thatch down. The same term, lange, is used to refer to the necklace that is sometimes given by the mother's brother for his sister's child thus 'purchasing' the child and averting life-threatening influences believed to follow the child's father's line. It is also used to refer to the neck-halters that are sometimes placed on the necks of goats or pigs to hamper their movements. Finally there is the term for 'elbow' that is used in reference to the house. The 'outside elbows of the house' (uma si'u dea) refers to the corners of the house at the outer edge of the roof.

\section{The House as Oriented Structure and Inner Space}

The house is a complex classificatory structure. It is also a coherent structure. Given its basic directional orientation, its levels, and the common associations linked to these coordinates, all points and parts of the house can be given a symbolic identification. At this level, however, classification is not confined to a single schema. The layout of the house and its levels may be considered either as a dichotomous or as a trichotomous structure.

According to the more general dichotomous structure of the house, all aspects of the house can be arrayed as a set of complementary pairs. The principal symbolic operators for this classification are the directional coordinates as well as the categories of 'outside' and 'inside'. On this basis, the layout of the house is so ordered that its 'eastern' half, which forms the 'head' of the house, is categorized as 'outside' in opposition to its 'western' half, which forms the 'tail' 
of the house, and is categorized as 'inside'. This complementary classification is asymmetric. The house is constructed to consist of unequal halves with the 'eastern' half being the larger structure. According to the rules of construction, the 'head' or 'outer house' must have an odd number of spars as opposed to the 'tail' or 'inner house', which must have an even number. Following the standard valorization or 'markedness' set by the directional coordinates (see Fox 1989), the categorical asymmetry of the house can be expressed in the following polarities:

\section{Polarities of the House}

$\begin{array}{ll}(+) & (-) \\ \text { East } & \text { West } \\ \text { Head } & \text { Tail } \\ \text { Outside } & \text { Inside } \\ \text { Odd } & \text { Even }\end{array}$

This categorical asymmetry within the house represents one mode of classification. It conforms, to a considerable degree, to the representation of the house as a personified creature - crocodile, water-buffalo or human.

If, however, one focuses on the critical categories of outside/inside, another mode of classification emerges. Thus the Rotinese house may be seen as a progressive spatial delineation of the category of 'inside' (dale-), which is identified as 'female'. Thus all of the space under the low-hanging roof of the house is defined as 'inside', as indeed the house as a whole is associated with a woman. Similarly all of the space enclosed within the first raised level of the house is also considered 'inside' the house and is markedly so when the ladder is drawn up and this part of the house is closed to the outside. At this level, there is an important categorical division between the 'outer house' and the 'inner house' - a separation of precincts that is physically defined by a partition. Within the precinct defined as the 'outer house', however, there is a further dichotomy between the 'head' and 'inner middle' so that as one moves from east to west, one moves from the 'head', through the 'inner middle' of the house into the 'inner house'. If one follows this progression a step further, there is the ladder in the 'inner house' that leads up into the loft, the most sacred and restricted precinct 'inside' the house.

Herein lies the mystery of the Rotinese house: a reversal. By the conventions of the Rotinese directional coordinates, 'to go east' is 'to go up'. In the house, this structure is reversed: 'to go west' is 'to go up'. It involves going into an ever more circumscribed 'inner' space - a realm defined as 'female', a realm of the spirits, and a realm associated with the 'last-born' who retains the house and remains within it. It is also the realm associated with birth, with the cult of the 
'nine seeds' and, most importantly, with the hearth, which is the symbolic focus of the house as a social unit.

There is a further implicit transformation in this symbolism of the house. In the origin narrative, the basic structures of the first house - its posts and beams - were the 'sinews and bones' of the Lord of the Sea, the crocodile, who is always represented as a male predator. This male structure, however, becomes a female whole. In Rotinese terms, the posts and beams of the house are 'erected' (tetu), but only when the house is roofed is it made whole (tema). This wholeness is what makes the house 'female' and its inner precincts the most vital of all female cultural spheres.

\section{The Rotinese House as a Memory Palace}

The Rotinese house is the locus for a complex symbolism and for the interpretation of this symbolism. Much of this interpretation depends on an esoteric knowledge of the origin of the house in the sacrifice of the Lord of the Sea, on clever exegesis of specific references in the chants, and on a mature understanding of the general postulates of Rotinese culture; all of which are represented as cultural knowledge (lelak) that anyone may gradually obtain and thus become a 'person of knowledge' (hataholi malelak). This valued knowledge exists apart from the house. The house is the physical means of its remembrance. In this sense, the Rotinese house is indeed a memory palace and the frequent injunction 'to remember and to bear in mind' is appropriate. From the perspective of a 'person of knowledge', the traditional house could disappear and the knowledge it is supposed to embody might continue. For others, the disappearance or radical transformation of the house would entail a fundamental alteration of a cultural understanding.

In 1965-66, at that time of my first fieldwork, an overwhelming majority of houses followed what was considered to be the traditional building pattern. ${ }^{6}$ At that time, however, there were vigorous arguments about which houses followed this pattern closely and which houses had flaws in their construction. Flaws - the use of a nail where something should have been tied or the misplacement of a particular spar - were indicative of some misfortune that might befall members of the house. Most houses at the time used permanent stepped ladders rather than the tree-trunk ladders that could be pulled up into the house. This was acceptable and no longer courted disaster. On the whole, it could be said that most houses conformed to a recognized standard. A few houses were magnificent examples of this standard. Only the houses of schoolteachers and a minority of progressives, many of whom had lived on other islands, were built on the ground without reference to this standard.

By 1972 when I returned to Roti, a local government campaign had begun to tear down traditional houses on the would-be hygienic grounds that such 
houses were closed, sunless and unhealthy. The modernists who waged this campaign were mainly Rotinese intent on rapid and radical development. The house was rightly seen as the locus for traditional practice, but Christianity as well as health and development were invoked in an effort to replace the sloping-roofed 'haystack' houses with high-roofed, wide-windowed houses built on the ground. Sadly, the campaign was largely successful in Korbaffo and Termanu. Although the finest of the old structures need not have been targeted for destruction, it was inevitable that changes would have to occur in building techniques. The quality hardwood needed especially for posts, beams and the ridge-pole was becoming extremely scarce and the costs of building a solid traditional house were increasingly prohibitive.

During the 1970s, the transition to other building techniques began in earnest and was strongly encouraged by local officials. The increasing availability of relatively low cost cement and the lack of good timber prompted the building of some interesting and innovative cement and stone structures. Many traditional houses remained in various locations and by the 1980s, their potential as tourist attractions insured their preservation. Crucially, the fear that a flawed or altered house form might lead to disaster had receded but the argument over what constituted the essentials of a traditional house continued. If a house was built in proper east - west alignment, if it retained its four 'orphan spars' (or, in other words, was built in a rectangular form), if it preserved a relationship between 'outer' and 'inner' sections, and if it combined these features with a loft, did it not conform to a traditional pattern?

Certainly for the Rotinese, tradition is not some rigid framework that imposes itself on the present. It is rather a relationship with the past. If one reads the various Rotinese accounts recorded by the Dutch linguist J.C.G. Jonker at the turn of the century, one can already detect arguments over the nature of the 'traditional' house by reference to its contrary, the non-traditional house. This was a house built on the ground (uma daek) which was considered to be a European-style house (uma filana). By this time, however, a crucial change had already been imposed from above by the Dutch on the traditional Rotinese house. In the nineteenth century, the dead - or perhaps more correctly, the honoured dead - were buried underneath the house. The Dutch, for health reasons, forbad burial beneath the house and most burials were thereafter shifted to the courtyard in close proximity to the house. Thus the original Rotinese house was also a tomb. The spirits of the dead were represented by lontar leaves in the loft while their bones were buried in the earth below. ${ }^{7}$ The symbolic operators, above (lai)/below (dae), had a greater significance in this house-and-tomb than they did after the dead were displaced from the ground below. Important aspects of the mortuary rituals had to be reinterpreted to accommodate these critical changes. One could argue therefore that the symbolic importance of a raised structure was already seriously undermined by forced changes in the nineteenth 
century. If such fundamental changes could be accommodated with a traditional understanding of the house, it is evident that the house has indeed served as a memory palace to transmit selectively certain ideas of the past. Despite the exhortation 'to remember and bear in mind', memories have altered with time.

\section{COMPARATIVE POSTSCRIPT}

\section{Points of Comparison Between Houses on Roti and on Timor}

In eastern Indonesia an understanding of the house embraces more than its physical structure and the symbolic significance attached to its parts. The house defines a fundamental social category. House structures are particular local representations of this wider conception. They define what is generally regarded as a 'descent group' but might more appropriately be referred to, in Austronesian terms, as an 'origin group'. This group is of a variable segmentary order (Fox 1980b:11). This variability is crucial to the concept of the house. It provides a sliding scale that may be associated with different physical structures depending on the development of the group, its conception of its origin and its relation to other groups, and the context within which it is considered. As a consequence, there can be no strict definition of the house as a social category since even within the same society the house embraces a range of possibilities.

Generally the societies of eastern Indonesia possess a category that identifies a social group larger than the house. On Roti this is the leo. Elsewhere, as for example among the Atoni Pah Meto of west Timor, it is the kanaf; among the Tetun of Wehali, the fukun; among the Ata Tana Ai of Flores, the suku; among the Savunese, the $u d u$; throughout Sumba, it is the kabisu or kabihu. In the literature on the region this category is generally denoted by the term 'clan'.

'Houses' - often with specific ancestral names - make up units within the clan. Yet given the structural potential of the category 'house', in some instances a specific 'house' can claim to encompass, represent or head an entire clan. Thus at one level, and within a defined context, a 'house' can embrace the highest-level social unit of the society of which it is a part. More commonly, however, the 'house' refers to lesser social units. These houses may be identified in relation to some encompassing house - real or remembered — from which they originate. They may be referred to by their attributes or by their founding ancestors, or by the portion of the heirlooms and prerogatives that they have inherited from an earlier house. At a minimum, houses of this sort define social groups that are primarily, though not exclusively, involved in the arrangement of marriages and the performance of most rituals of the life cycle. At this level, houses are the basic units of society (Fox 1980b:10-12).

Houses, as physical entities, are supposed to manifest the characteristics of the social categories and groups that they represent. These, too, are variable 
structures. In the literature on eastern Indonesia, however, descriptions of the 'house' represent models of an idealized structure: a schematic order of the kind described for the Rotinese house. Even at this abstract level, it is difficult to compare one house with another because the descriptions of these houses portray elaborate structures that are overladen (over-determined, perhaps) with cultural significance. The variety of these structures and the different conceptions attached to them would seem to frustrate basic comparison. With such richness, it is difficult to know what elements ought to form the focus of comparison. The identification of a few common structures among closely related societies may, however, provide a clue to some of the important features of the house.

Here I would like to venture a number of comparisons based on the orientation of the house and on consideration of a limited set of its important named structures. These 'points of comparison' are intended to note both similarities and differences between related house structures. In an overall comparison, points of difference are as pertinent as points of similarity.

Because of the importance of the house in eastern Indonesia, the literature on these structures is extensive. For the purpose of comparison, I confine my consideration to the house structures of three distinct populations who are closely related, both linguistically and culturally. These populations are (1) the Rotinese, (2) the Atoni Pah Meto of west Timor and (3) the Ema of north central Timor.

My starting point is the orientation of these houses, which is fundamental. Thus, to be oriented at all, a house must have at least three axes, each of which constitutes one coordinate of the system. The first of these axes is the above/below, or up/down, axis. Since houses in eastern Indonesia are multilevel structures, this axis is important. As a coordinate, however, the up/down axis is virtually invariant among the societies of eastern Indonesia and is therefore less problematic than the other two axes whose identification may vary from society to society. Of these two axes, one appears to be primary in the sense that it is applied first and the other is applied in relation to it. As coordinates, these axes create a fourfold symbolic structure.

\section{The Atoni Pah Meto of West Timor}

Clark Cunningham (1973) has described the Atoni house of the domain of Amarasi in west Timor in an important article of exceptional clarity. Since the Rotinese and Atoni are related populations, the question of the relation of their houses to one another is pertinent. Although the Amarasi house (ume) has a beehive-like roof, it is in fact a four-post structure and therefore directly comparable to the basic four-post Rotinese house (uma di hak). In the Atoni language, these four posts are referred to as the 'mother posts' (ni ainaf). Note that $d i$ and $n i$ are cognate terms, as are numerous other terms for similar items in the two houses. 
The Amarasi house is also oriented in a similar fashion to the Rotinese house. (Compare Figure 4, p.156, with Figure 9 below.) The equivalent of the east/west (dulu/muli) or head/tail (langa/iko) axis of the Rotinese house is, among the Atoni, the axis of the sunrise/sunset (neonsaen/neontes). Similarly, as on Roti, right for the Atoni is south $\left(n e^{\prime} u\right)$ and left is north $\left(a l i^{\prime}\right)$. The door of the Rotinese house may open to the north or the south; the door of the Amarasi house should be oriented to the south. This orientation produces a system of four corners referred to in Timorese as the 'great quarters' (suku naek). The colours associated with these quarters are also the same as on Roti: east is white, south is red, west is black and north is (green-)yellow. To this point, therefore, there is a virtual one-to-one correspondence of the orientation coordinates and their associations from one house to the other.

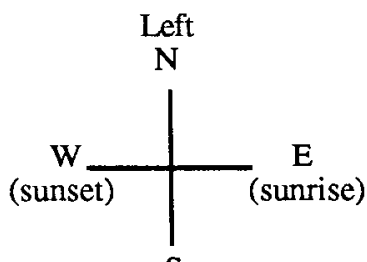

S

Right

a mone: outside, male (yard)

b eno: door

c toi: entrance

d tunaf: hearth

e nanan: inside, centre (inner section)

f harak ko'u: great platform

g harak tupa: sleeping platform

$\mathrm{h}$ harak manba'at: agreement platform (serving platform)

i nai oe teke : fixed water jar

j ni ainaf: mother post

$\mathrm{k}$ ni ainaf (nakan): mother post (head)

l toi: entrance (attic)

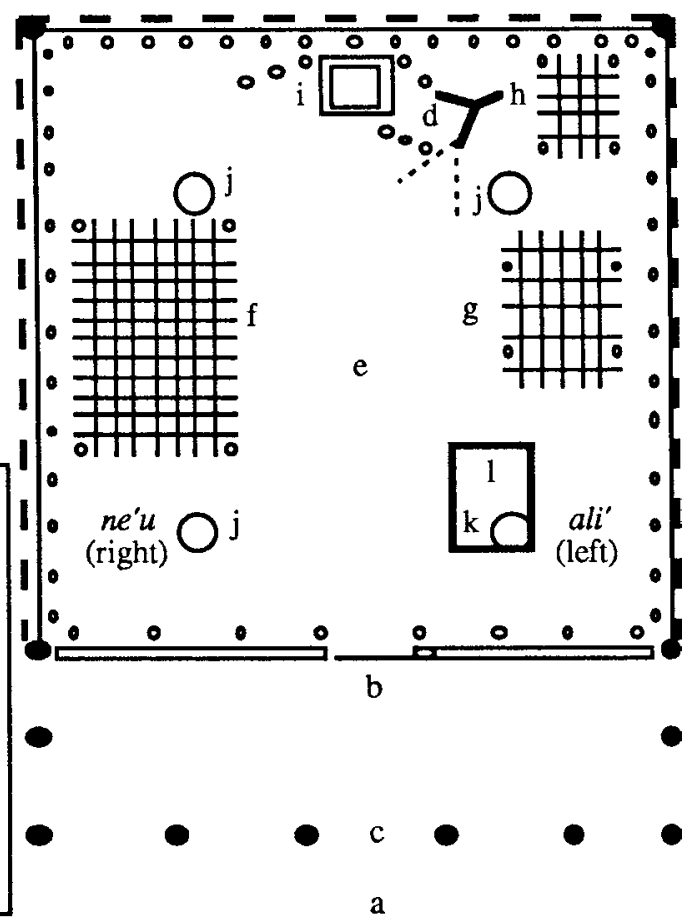

Figure 9. Floor plan of an Atoni house (adapted from Cunningham 1964:38)

There are, however, significant differences. Like the Rotinese, the Atoni make a distinction between 'inside' and 'outside'. This distinction also implies a distinction between 'female' and 'male' especially since the term mone among the Atoni means both 'male' and 'outside'. In relation to the Atoni house, the yard is referred to as mone while everything under the roof is the 'inside of the house' (ume nanan). There is, however, a further distinction made between the whole of this ume nanan and what is called simply the 'inside' (nanan). The 'elbow' (si'u) of the house under the roof has platforms for receiving affines and 
guests but is separated by a partition from the 'inside' (nanan) precinct of the house which is reserved exclusively for members of the house and close agnatic relatives. All of this is functionally equivalent to the Rotinese distinction between the 'inner' and 'outer' sections of the house. Although cognate terms occur, such as the word $s i^{\prime} u$ for 'elbow' in both languages, correspondences are different because the symbolic location of key objects and structures among the Atoni is entirely within the 'inside' house rather than being divided between 'inner' and 'outer' sections of the house among the Rotinese.

Orientation within the 'inside' house is crucial. For the Amarasi house, the right/left distinction is variably applied absolutely and relatively. Thus, as a directional coordinate, the right/left axis sets the basic orientation of the house. Within the house, however, the right/left distinction is applied relative to a person looking out the door of the 'inside' house. The superimposition of this interior distinction on the basic orientation system produces a situation where internally 'right' is on the 'sunset' side of the house and 'left' on the 'sunrise' side. Key objects and structures are positioned according to this second relative right/left orientation which is associated with an opposition between 'male' and 'female'. This produces a bifurcation through the house equivalent to the outer/male and inner/female opposition in the Rotinese house. Accordingly much of the right side of the house is taken up with a platform known as the 'great platform' (harak ko'u) on which tools, possessions, pounded corn and rice are kept. In the centre of the house - slightly to the left but never to the right is the hearth (tunaf). The hearth may also be placed further back on the left side of the house near the 'fixed water jar' (nai oe teke) and what is called the 'agreement platform' (harak manba'at). This platform holds cooking utensils and cooked food, but it is also where a woman is placed when she gives birth and is later 'cooked' and bathed with hot water during a period of confinement. Also located on the left is a sleeping platform for the elder man and woman of the house.

Of the four principal posts of the Amarasi house, one post known as the 'head' (nakaf) is singled out for special ritual attention. This post has a flat stone altar at its base and sacred ancestral objects are tied to it. It is called the 'head' because there is a hatch next to it that leads up into the loft. In terms of the interior orientation of the house, this 'head' post is at the front and left, but in terms of the general orientation of the four quarters, this 'head' is at the south-east corner of the house and thus in exactly the same position as the 'right' post in a Rotinese house. From this perspective, the basic orientation of the two houses is retained; the difference is that the Rotinese house maintains a single systemic orientation, whereas the Atoni house has an internal orientation that overrides the 'external' Atoni orientation system. Access to the loft in the Atoni house is near the 'head' post whereas in the Rotinese house, it is at the 'tail'. 


\section{The Ema of North Central Timor}

Brigitte Renard-Clamagirand $(1980,1982)$ has written with exceptional detail on the houses of the Ema of north central Timor. Particularly valuable is her discussion of the different categories of houses defined in relation to a core house, referred to as the 'house and hearth' (uma no apir) of the Ema descent group. Lesser houses within the group may either have specific functions such as the 'basketwork and enclosure house' (uma taka no lia) that has the task of caring for a sacred buffalo stone (bena) or the 'water and tree house' that must care for palm trees in irrigated gardens; or, they may simply be 'middle of the field houses' (uma asa laran) that are dependent on higher ranking houses for the sacred objects needed to perform their rituals (1980:136-138).

According to Renard-Clamagirand (1982:37-48), all houses (uma) are built on the same plan and differ only in their relative dimensions (see Figure 10). This plan defines a raised square structure with four walls and an open front veranda enclosed under a conical roof. The house is distinguished from the granary (lako) which consists of a relatively simple raised platform enclosed under a less extended conical roof. For the purposes of storage, the granary functions as the equivalent of the loft in the Rotinese house.

The orientation of the Ema house is remarkably similar to that of the Rotinese and Amarasi houses. The house is oriented on an east-west axis according to the directions of sunrise (lelo saen) and sunset (lelo du). Its veranda (golin), and the door (nito) that leads into the 'inner house' (uma laran), face to the south. On entering the house from the veranda, there is a basic dichotomy. The sunrise half of the house is called the 'great platform' (soro boten) and the sunset half the 'lesser platform' (soro bi'in). Ritual focus in this divided 'inner house' concentrates on two posts, categorized as 'male' and 'female' located at the sunrise and sunset ends of the house. The 'male head post' (ri ulun mane) defines the 'greater platform' as pre-eminently male, just as the 'female head post' ( $r i$ ulun ine) defines the 'lesser platform' as female. The other feature of the 'lesser platform' that defines it as female space is the presence of the hearth (api matan). 
Memories of Ridge-Poles and Cross-Beams: The categorical foundations of a Rotinese cultural design
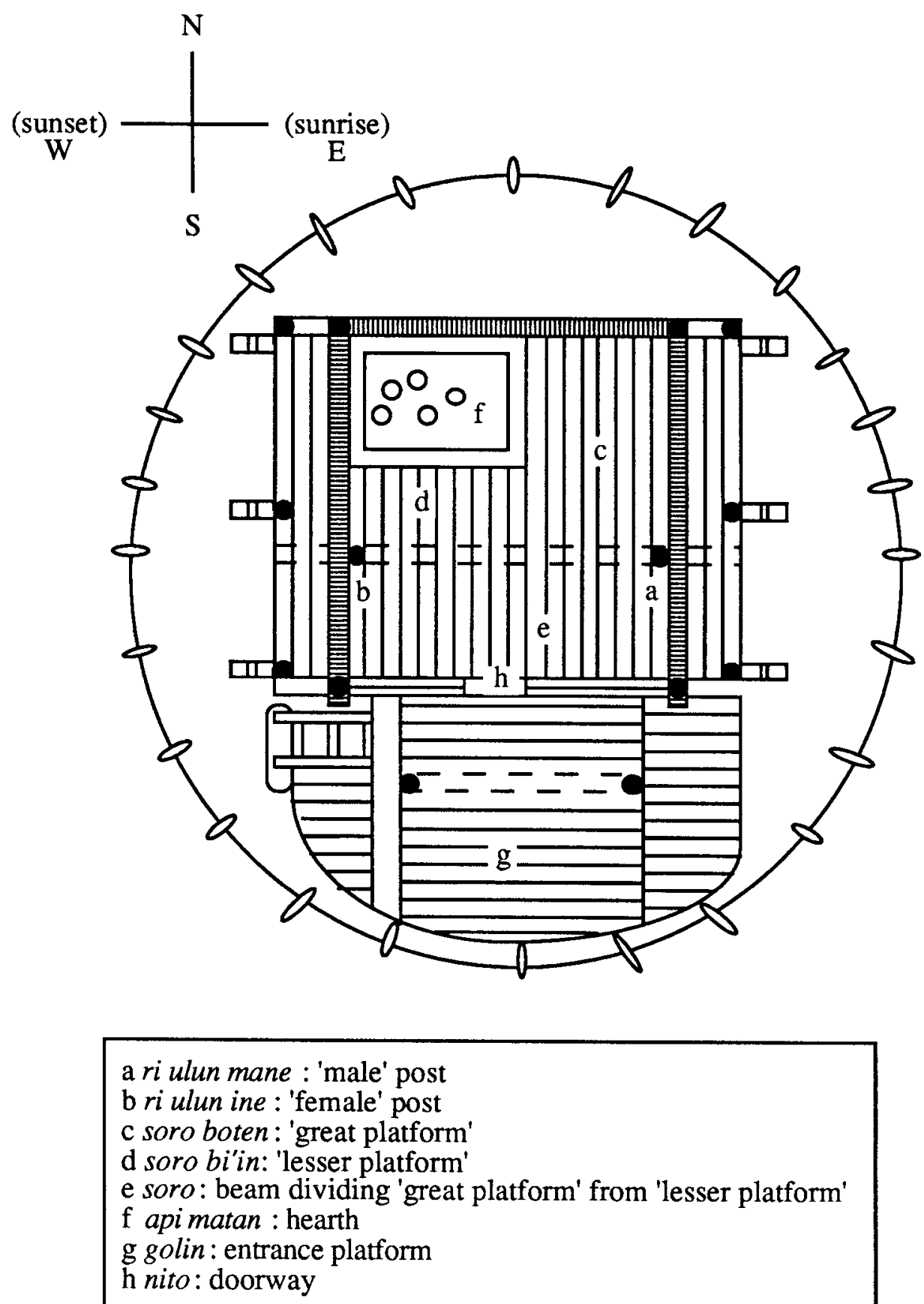

Figure 10. Floor plan of an Ema house (adapted from Renard-Clamagirand 1982:41) 


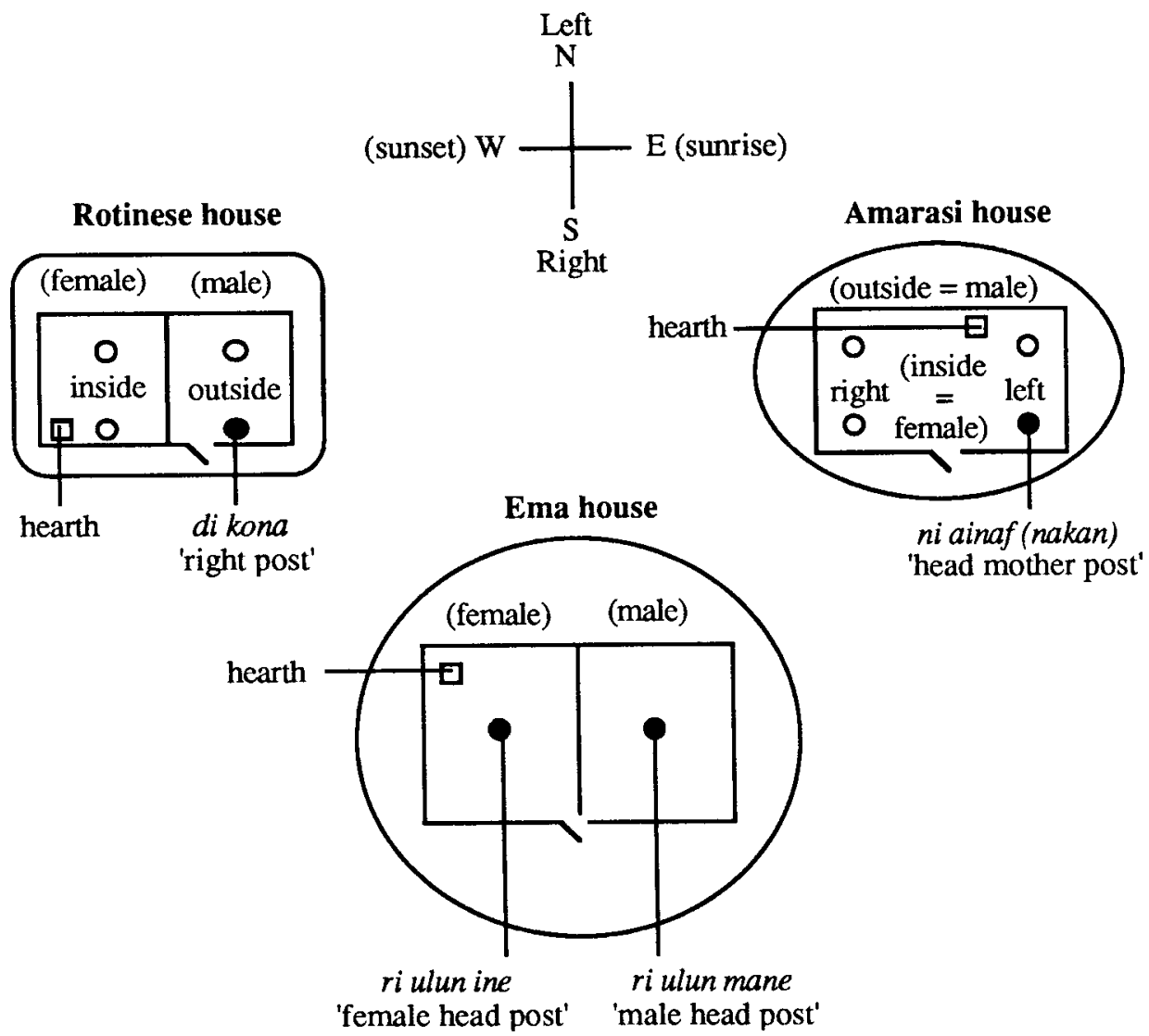

Figure 11. Comparison of the layouts of Rotinese, Atoni and Ema houses

In the Rotinese and Amarasi houses, ritual focus is on one of four posts; in the Ema house, it is divided between two posts that are considered as male and female. In general orientation and in the delineation of the 'inner' house, however, the Ema house resembles the houses of both the Rotinese and Timorese of Amarasi. Within the Rotinese house, the dichotomy is between 'inside' and 'outside'; in the Amarasi, it is between 'right' and 'left'; while in the Ema house, it is between 'male' and 'female'. Because of the relative application of 'right' and 'left' in the Amarasi house, the 'great platform' is located on the 'right' but at the sunset side of the house whereas in the Ema house, the 'great platform' is located in the 'male' half of the house which is on the sunrise side of the house. In all three houses, the chief post (post in Rotinese, di; Atoni, ni; Ema, ri from proto-Austronesian ${ }^{*} \mathrm{SaDiRi}$ ) - the principal ritual attractor of the house - is on the eastern or sunrise side. In the Rotinese and Amarasi, it is the south-eastern quadrant of the house. In all three houses, the hearth is given 'female' associations: for the Rotinese, it is 'inside'; for the Atoni, it is on the 'left'; and for the Ema, the hearth occupies a large segment of the 'female' half of the house. 
It is interesting to note the shifting location of this hearth in relation to the main 'attractor' in the house. For the Rotinese, the hearth is in the south-west quadrant; for the Atoni, the north-east; and for the Ema, the north-west. Figure 11 provides a schematic representation of these various similarities and differences. One can begin, by means of this schematic representation, to discern how these structures may be related to one another.

\section{References}

Cunningham, C.E.

1973 Order in the Atoni house (revised version). In Rodney Needham (ed.) Right and left: essays on dual symbolic classification, pp.204-238. Chicago: The University of Chicago Press. (Orig. pub. 1964.)

Fox, James J.

1971 Sister's child as plant: metaphors in an idiom of consanguinity. In Rodney Needham (ed.) Rethinking kinship and marriage, pp.219-252. London: Tavistock.

1973 On bad death and the left hand: a study of Rotinese symbolic inversions. In Rodney Needham (ed.) Right and left: essays on dual symbolic classification, pp.342-368. Chicago: The University of Chicago Press.

1974 "Our ancestors spoke in pairs": Rotinese views of language, dialect and code. In Richard Bauman and Joel Sherzer (eds) Explorations in the ethnography of speaking, pp.65-85. Cambridge: Cambridge University Press.

1975 On binary categories and primary symbols: some Rotinese perspectives. In Roy Willis (ed.) The interpretation of symbolism, pp.99-132. London: Malaby Press.

1980a Obligation and alliance: state structure and moiety organization in Thie, Roti. In James J. Fox (ed.) The flow of life: essays on eastern Indonesia, pp.98-133. Cambridge, Mass.: Harvard University Press.

1980b Introduction. In James J. Fox (ed.) The flow of life: essays on eastern Indonesia, pp.1-18. Cambridge, Mass.: Harvard University Press.

1988 "Chicken bones and buffalo sinews": verbal frames and the organization of Rotinese mortuary performances. In Henri J.M. Claessen and David Moyers (eds) Time past, time present, time future: essays in honour of P.E. de Josselin de Jong (Verhandelingen van het Koninklijk Instituut voor Taal-, Land- en Volkenkunde 131), pp.178-194. Dordrecht: Foris Publications.

1989 Category and complement: binary ideologies and the organization of dualism in eastern Indonesia. In David Maybury-Lewis and Uri Almagor 
(eds) The attraction of opposites: thought and society in a dualistic mode, pp.33-56. Ann Arbor: University of Michigan Press.

Jonker, J.C.G.

1913 Bijdragen tot de kennis der Rottineesche tongvallen. Bijdragen tot de Taal-, Land-en Volkenkunde van Nederlandsch-Indië 68:521-622.

Renard-Clamagirand, Brigitte

1980 The social organization of the Ema of Timor. In James J. Fox (ed.) The flow of life: essays on eastern Indonesia, pp.134-151. Cambridge, Mass.: Harvard University Press.

1982 Marobo: une societé ema de Timor (Langues et civilizations de l'Asie du Sud-Est et du monde insulindien No. 12). Paris: SELAF.

Spence, Jonathan D.

1984 The memory palace of Matteo Ricci. New York: Viking Penguin.

Wetering, F.H. van de

1923 Het Roteneesche huis. Tijdschrift voor Indische Taal-, Land- en Volkenkunde 62:452-495.

Yates, Frances A.

1966 The art of memory. London: Routledge \& Kegan Paul.

1969 Theatre of the world. Chicago: The University of Chicago Press.

\section{Notes}

1 It was this mnemonic art that Jesuits like Matteo Ricci are said to have introduced to Asia in the sixteenth century (Spence 1984).

2 Frances Yates, in her book Theatre of the world (1969), has examined the development of the English public theatre, including the Globe, in relation to ideas that derive from the classical art of memory.

3 These seeds are also identified as the 'nine children' of the figure known as Lakimola and thus the cult and the basket representing it are referred to simply as 'Lakimola'.

${ }^{4}$ Van de Wetering (1923:479-480) includes short prayers to both these figures in his description of the house rituals of Bilba.

${ }^{5}$ A good deal of everyday cooking may be done in a hut built outside the house. This kind of structure is generally located at the 'tail' of the main house. Such an arrangement does not diminish the symbolic importance of the hearth within the house.

${ }^{6}$ It is worth noting that when my wife and I took up residence in Ufa Len in Termanu we were offered accommodation in a non-traditional house built on the ground with a cement foundation, windows and a tin roof. The house was built by a man who lived in a traditional house and was the only house of its kind in a cluster of traditional houses. As far as I could determine, the house had been built - it was not quite finished when we arrived - as fancy but temporary accommodation that might attract a suitable high-status bride for the man's only son who would eventually inherit his father's house.

7 In the 1970s it was still possible to find old houses where individuals remembered the location of specific relatives who were buried under the house. Until the early 1970s, this practice continued in a low key fashion in that the bodies of infants who lived for only a few days were often buried at the foot of the house ladder or at the threshold of the house in hope of their imminent return to the house. 

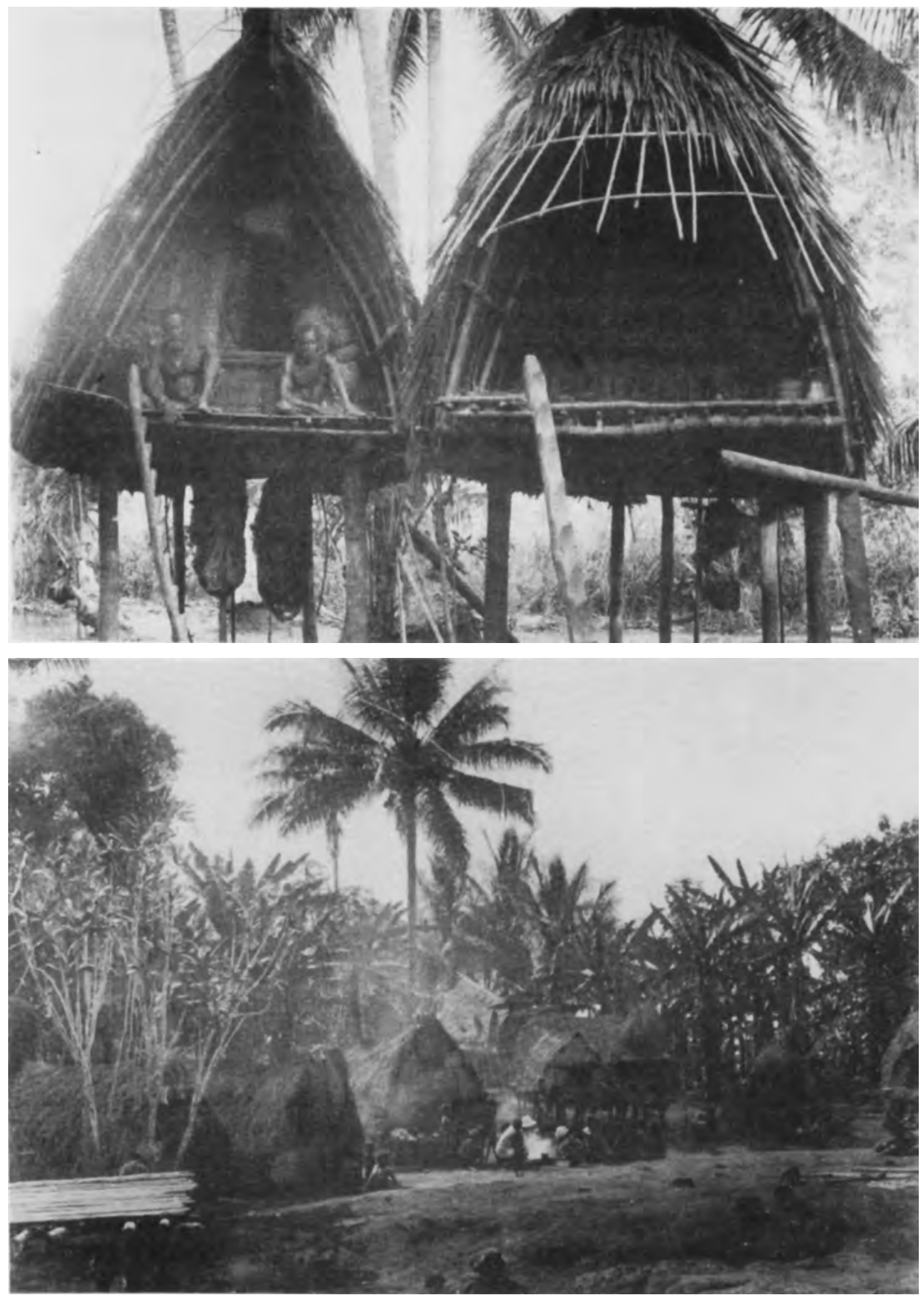

Goodenough Island houses circa $1912^{1}$

1 The top photograph is a print from a glass plate photograph taken by anthropologist Diamond Jenness in 1912. His caption reads, 'General view, Minafane village. Ballantyne boiling billy'. Minafane was a small village in the hills behind Bwaidoga in south-east Goodenough. Today the descendants of Minafane 
people dwell on the coast. Andrew Ballantyne was Jenness' brother-in-law and the Methodist missionary at Bwaidoga from 1905 to 1915 . The bottom photograph was also taken by Jenness in 1912. His caption reads, 'Two houses from gable end, Vatalumi, Goodenough Island; raised, leaf thatch, platform shielded by roof projection, notched log ladder. Two men on platform'. Vatalumi (today Wataluma) is in the north-east of the island. Both photographs are reproduced with the permission of the Pitt-Rivers Museum, Oxford. 